\author{
Maciej KOKOSZKO \\ Jolanta DYBAŁA \\ Krzysztof JAGUSIAK \\ Zofia RZEŹNICKA*
}

\title{
DIETA MONASTYCZNA W ŚWIETLE NAUKI MEDYCZNEJ Teodoret z Cyru i medycy o soczewicy ${ }^{* *}$
}

Teodoret (ok. 393 - ok. 466), duchowny, teolog i pisarz chrześcijański ${ }^{1}$, to autor, któremu zawdzięczamy stworzenie jedynego źródła pozwalającego nam poznać historię ascetów żyjących w Syrii w okresie od początku IV do połowy V w. Są to Dzieje miłości Bożej ( tytuł brzmi Historia religiosa ${ }^{2}$. Pismo prezentuje trzydzieści żywotów syryjskich mnichów, którzy zmierzają do osiągnięcia duchowej doskonałości ${ }^{3}$. Na

${ }^{*}$ Dr hab. Maciej Kokoszko, prof. UŁ - kierownik Katedry Historii Bizancjum w Instytucie Historii na Wydziale Filozoficzno-Historycznym Uniwersytetu Łódzkiego; e-mail: mkokoszko@ komandor.pl; dr Jolanta Dybała - absolwentka historii w Instytucie Historii na Wydziale Filozoficzno-Historycznym Uniwersytetu Łódzkiego; e-mail: j.dybala@vp.pl; mgr Krzysztof Jagusiak - doktorant przy Katedrze Historii Bizancjum w Instytucie Historii na Wydziale Filozoficzno-Historycznym Uniwersytetu Łódzkiego; e-mail: krzysztof_jagusiak@o2.pl; mgr Zofia Rzeźnicka - doktorantka przy Katedrze Historii Bizancjum w Instytucie Historii na Wydziale Filozoficzno-Historycznym Uniwersytetu Łódzkiego; e-mail: zosia_pwp.historyk@wp.pl.

** Artykuł został napisany w związku z grantem 2011/01/BHS3/01020.

${ }^{1}$ Po szczegółowe informacje dotyczące życia, poglądów teologicznych i spuścizny literackiej biskupa Cyru odsyłamy Czytelnika m.in. do: R.M. Price, Introduction, w: Theodoret of Cyrrhus, A History of the Monks of Syria, transl., introd., notes R.M. Price, Kalamazoo 1985, IX-XXXVII; Altaner, s. 454-457; M. Karas, Apologetyka Teodoreta z Cyru wobec filozofii Platona, VoxP 21 (2001) t. 40-41, 317-335; Th. Urbainczyk, Theodoret of Cyrrhus. The Bishop and the Holy Man, Ann Arbor 2002; S. Longosz, Szkoła antiocheńska, w: Literatura Grecji starożytnej, II: Proza historyczna, krasomówstwo, filozofia i nauka, literatura chrześcijańska, red. H. Podbielski, Lublin 2005, 1061-1067; M. Kieling, Kościót jako wspólnota miłości w świetle „Komentarza do 1 Listu św. Pawta do Koryntian" Teodoreta z Cyru, KaST 5 (2006) 191-206; I. Pasztori-Kupan, Theodoret of Cyrus, London - New York 2006, 3-80; P.B. Clayton, The Christology of Theodoret of Cyrus. Antiochene Christology from the Council of Ephesus (431) to the Council of Chalcedon (451), Oxford 2007; A.M. Schor, Theodoret's People. Social Networks and Religious Conflict in Late Roman Syria, Berkeley - London 2011.

${ }^{2}$ Theodoretus, Historia religiosa, PG 82, 1283-1496. Polskie thumaczenie tekstu: Teodoret biskup Cyru, Dzieje miłości Bożej. Historia mnichów syryjskich, tłum. K. Augustyniak, wstęp E. Wipszycka - K. Augustyniak, ŹM 7, Kraków 20113.

${ }^{3}$ Por. K. Augustyniak, Wstęp. Historia mnichów syryjskich, w: ŹM 7, 37-50. Z opracowań 
drodze do realizacji tego celu staje im świat zewnętrzny i jego pokusy. Opisy wewnętrznej walki, jaką toczą mężowie pustyni, są dla czytelnika okazją do zapoznania się z pewnymi szczegółami dotyczącymi prozy ich dnia codzienne$\mathrm{go}^{4}$. Do owych detali zaliczają się informacje na temat rodzaju i ilości spożywanego przez nich pokarmu oraz technologii jego obróbki ${ }^{5}$. Wynika to z faktu, iż asceci upatrywali swojego wroga między innymi we własnym ciele oraz jego potrzebach ${ }^{6}$, a za jedno z narzędzi walki z nimi obrali sobie wycieńczającą organizm dietę ${ }^{7}$ którą niejednokrotnie przerywali długimi okresami postu ${ }^{8}$.

traktujących o monastycyzmie syryjskim wymienić należy przede wszystkim: A. Vööbus, History of Asceticism in the Syrian Orient. A Contribution to the History of Culture in the Near East, II-III: Early Monasticism in Mesopotamia and Syria, Louvain 1960-1988; P. Canivet, Le monachisme syrien selon Théodoret de Cyr, Paris 1977; Ph. Escolan, Monachisme et Église. Le monachisme syrien du $I V^{e}$ au VII siècle. Un ministère charismatique, Paris 1999. Z prac w języku polskim np.: H. Dybski, Monastycyzm w Palestynie i Syrii w świetle źródet patrystycznych IV i V wieku, VoxP 22 (2002) t. 42-43, 411-436; E. Wipszycka, Wstęp. Charakter i formy ascetyzmu syryjskiego, w: ŹM 7, 9-36; L. Misiarczyk, Antyczny monastycyzm syryjski, StPł 40 (2012) 83-96.

${ }^{4}$ Por. P. Allen, Homilies as a Source for Social History, StPatr 24 (1993) 1-5; P. Szczur, Problematyka społeczna w późnoantycznej Antiochii na podstawie nauczania homiletycznego Jana Chryzostoma, Lublin 2008, 9-12.

${ }^{5}$ Por. M. Kokoszko - K. Gibel, Dieta mnichów syryjskich. Komentarz do terminu autofya lachana ( $\alpha$ $\tau 0 \varphi v \hat{\alpha} \lambda \alpha \dot{\alpha} \chi \alpha v \alpha) w$ Historia religiosa Teodoreta z Cyru, w: Omnia tempus habent. Miscellanea theologica Vincentio Myszor quadragesimum annum laboris scientifici celebranti ab amicis, sodalibus discipulisque oblata, red. A. Reginek - G. Strzelczyk - A. Żądło, Katowice 2009, 145156. Por. uwagi zawarte w E. Kislinger, How Reliable is Early Byzantine Hagiography as an Indicator of Diet?, „Diptycha” 4 (1986/1987) 5-11.

${ }^{6}$ Por. Wipszycka, Wstep, s. 18-19.

${ }^{7}$ Mnisi uważali, że jedzenie powinno być skromne i tanie (por. Theodoretus, Historia religiosa X 3, PG 83, 1389), a spożywać się je powinno tylko w ilości potrzebnej do utrzymania się przy życiu (por. tamże, Prologos 5, PG 83, 1289; I 2, PG 83, 1293; III 3, PG 83, 1325; V 3, PG 83, 1353; XI 3, PG 83, 1396). Zob. V.E. Grimm, From Feasting to Fasting. The Evolution of a Sin. Attitudes to Food in Late Antiquity, London 1996, 95-96; E. Kislinger, Christians of the East. Rules and Realities of the Byzantine Diet, w: Food. A Culinary History from Antiquity to the Present, ed. J.-L. Flandrin M. Montanari, Eng. ed. A. Sonnenfeld, New York - Chichester 1999, 199-201.

${ }^{8}$ Niektórzy mnisi spożywali posiłek raz dziennie - wieczorem (por. Theodoretus, Historia religiosa III 3, PG 83, 1325; III 12, PG 83, 1333; VIII 3, PG 83, 1369; XVII 6, PG 83, 1424), inni co kilka dni (por. tamże IV 5, PG 83, 1344; IX 3, PG 83, 1380) lub raz w tygodniu (np. tamże II 2 , PG 83, 1305; XXI 11, PG 83, 1437; XXVI 5, PG 83, 1468). W skrajnych przypadkach post mógł trwać nawet czterdzieści dni (por. tamże XXVI 7, PG 83, 1469; XXIX 7, PG 83, 1492; Euzebiusz w trakcie siedmiotygodniowego postu zjadł tylko piętnaście suszonych fig, por. tamże XVIII 4, PG 83, 1428). O roli postu we wczesnym chrześcijaństwie m.in. w: R. Arbesmann, Fasting and Prophecy in Pagan and Christian Antiquity, „Traditio” 7 (1949-1951) 1-71; H. Musurillo, The Problem of Ascetical Fasting in the Greek Patristic Writers, „Traditio” 12 (1956) 1-64; K.M. Dugan, Fasting for Life. The Place of Fasting in the Christian Tradition, „Journal of the American Academy of Religion" 63 (1995) 539-548; T.M. Shaw, The Burden of the Flesh. Fasting and Sexuality in Early Christianity, Minneapolis 1998; S. Bralewski, Praktykowanie postu w świetle historiografii kościelnej V wieku, VoxP 33 (2013) t. 59, 359-378. Kościół potępiał ascezę, w tym post, prowadzącą do 
Niniejszy artykuł ma na celu przybliżenie jednego z zagadnień składających się na obszerny temat, jakim jest dieta mnichów syryjskich ${ }^{9}$. Zajmiemy się w nim wzmiankowaną wyżej soczewicą i postaramy się ustalić, jakie jej zalety zadecydowały o tym, że asceci, o których opowiada Teodoret, tak chętnie po nią sięgali. Realizując nasz zamiar, odwołamy się najpierw do Historia religiosa Teodoreta z Cyru, a następnie przejdziemy do traktatów medycznych powstałych u schyłku starożytności i w erze wczesnobizantyńskiej, czyli w okresie od II do VII w. po Chr. Zwrócenie się ku źródłom tak odległym gatunkowo i tematycznie od Dziejów mitości Bożej autorstwa biskupa Cyru wynika z faktu, iż stanowią one kompendium wiedzy antyku i Bizancjum na temat roślin jadalnych ${ }^{10}$. Jesteśmy przekonani, że ich twórcy, ówcześni lekarze, formułując swoje poglądy odnośnie do wpływu poszczególnych produktów żywnościowych na ludzki organizm, bazowali na własnej wiedzy na ich temat. Mogli ją nabyć poprzez poznanie współczesnych im receptur i technik kucharskich. Tym samym ich dzieła stanowią cenny materiał służący pomocą również w odtworzeniu powszednich praktyk kulinarnych ${ }^{11}$. Zamknięcie naszych rozważań w szerszych ramach chronologicznych niż te, jakie wyznacza Historia religiosa, uzasadniamy ciągłością toposów powtarzanych w traktatach, do których sięgamy ${ }^{12}$.

krańcowego wyczerpania organizmu, por. K. Ware, The Way of the Ascetics. Negative or Affirmative?, w: Asceticism, ed. V.L. Wimbush - R. Valantasis, New York - Oxford 1995, 8-12.

${ }^{9} \mathrm{Na}$ skrupulatną analizę i opis całości tej tematyki potrzeba byłoby znacznie więcej miejsca. Ciekawe próby zbadania tego zjawiska dotyczą monastycyzmu w ogóle i nie bazują na danych Teodoreta. Por. M. Dembińska, Diet. A Comparison of Food Consumption Between Some Eastern and Western Monasteries in the 4th-12th Centuries, „Byzantion” 55 (1985) 431-462; M. Harlow W. Smith, Between Fasting and Feasting. The Literary and Archaeobotanical Evidence for Monastic Diet in Late Antique Egypt, „Antiquity” 75 (2001) 758-768; A. Dalby, Flavours of Byzantium, Totnes 2003, 93-97; A.-M. Talbot, Mealtime in Monasteries. The Culture of the Byzantine Refectory, w: Eat, Drink and Be Merry (Luke 12:19). Food and Wine in Byzantium. Papers of the 37th Annual Spring Symposium of Byzantine Studies, in Honour of Professor A.A.M. Bryer, ed. L. Brubaker - K. Linardou, Aldershot 2007, 109-125; L.A. Gregoricka - S.G. Sheridan, Ascetic or Affluent? Byzantine Diet at the Monastic Community of St. Stephen's, Jerusalem from Stable Carbon and Nitrogen Isotopes, „Journal of Anthropological Archaeology” 32 (2013) 63-73.

${ }^{10}$ Literaturę dietetyczną starożytności omawia M. Kokoszko w: Ryby i ich znaczenie $w$ życiu codziennym ludzi późnego antyku i wczesnego Bizancjum (III-VII w.), Łódź 2005, 9-23. O opiniach starożytnych na temat związku między dietą i stanem zdrowia człowieka zob. L. Edelstein, The Dietetics of Antiquity, w: Ancient Medicine. Selected Papers of Ludwig Edelstein, ed. O. Temkin C.L. Temkin, transl. C.L. Temkin, Baltimore 1967, 303-316 (spec. 311-312); I. Mazzini, Diet and Medicine in the Ancient World, w: Food. A Culinary History, s. 141-152; M. Kokoszko - Z. Rzeźnicka, Dietetyka w De re coquinaria, ,Przegląd Nauk Historycznych” 10 (2011) fasc. 2, 5-8.

${ }^{11}$ Por. M. Kokoszko, M. Kokoszko, Smaki Konstantynopola, w: Konstantynopol - nowy Rzym. Miasto i ludzie w okresie wczesnobizantyńskim, red. M.J. Leszka - T. Wolińska, Warszawa 2011, 471-472.

${ }^{12} \mathrm{O}$ tych toposach m.in. Dalby, Flavours of Byzantium, s. 127-169. 
1. Dieta mnichów syryjskich w oparciu o Historia religiosa Teodoreta z Cyru. Lektura dzieła Teodoreta skłania do wniosku, że pierwszoplanową

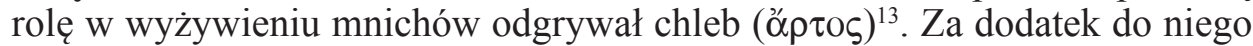
(ő $\psi$ ov) ${ }^{14}$ służyła sól (ő $\left.\lambda \varepsilon \varsigma\right)^{15}$. Na omawianą dietę składały się owoce. Duchowny odnosi się do nich, używając ogólnego pojęcia ỏ $\pi \hat{\omega} \rho \alpha \imath^{16}$, natomiast kon-

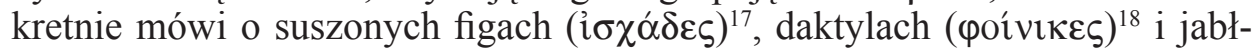
kach $(\mu \hat{\eta} \lambda \alpha)^{19}$. Ważne miejsce $\mathrm{w}$ tym menu musiały zajmować także jarzyny,

${ }^{13}$ Por. np. Theodoretus, Historia religiosa II 2, PG, 83, 1305. Unikano wyszukanych gatunków

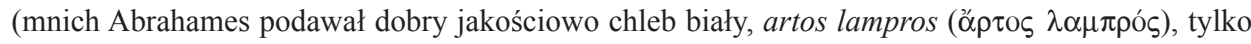
swoim gościom, por. tamże XVII 7, PG 83, 1424); jedzono chleb z prosa, por. np. tamże II 4, PG 83, 1308. Najgorliwsi mnisi potrafili rezygnować nawet z chleba - por. np. tamże III 21, PG 83, 1337; XIII 3, PG 83, 1401; XXVI 7, PG 83, 1469. Por. N. Jasny, The Daily Bread of the Ancient Greeks and Romans, „Osiris” 9 (1950) 227-253; K.D. White, Cereals, Bread and Milling in the Roman World, w: Food in Antiquity, ed. J. Wilkins - D. Harvey - M. Dobson, Exeter 1995, 38-43; Dalby, Flavours of Byzantium, s. 152 i 157; M. Rautman, Daily Life in the Byzantine Empire, Westport Oxford 2006, 46; J. Koder, Stew and Salted Meat - Opulent Normality in the Diet of Every Day?, w: Eat, Drink and Be Merry, s. 65-66; M. Toussaint-Samat, Historia naturalna i moralna jedzenia, przeł. A.B. Matusiak - M. Ochab, Warszawa 2008, 218-225; Kokoszko, Smaki Konstantynopola, s. 483-485; Z. Rzeźnicka - M. Kokoszko, Proso w gastronomii antyku i wczesnego Bizancjum, VoxP 33 (2013) t. 59, 401-419 (spec. 401-409).

14 "O wov oznaczał jakikolwiek dodatek do chleba - warzywa, owoce, słodycze, ser, mięso czy ryby. Z czasem znaczenie tego słowa zostało ograniczone wyłącznie do ryb, por. Toussaint-Samat, Historia naturalna, s. 219; Kokoszko, Smaki Konstantynopola, s. 508.

${ }^{15}$ Por. np.: Theodoretus, Historia religiosa II 2, PG 83, 1308; XI 1, PG 83, 1393; XX 3, PG 83, 1429. Na temat soli: A. Dalby, Food in the Ancient World from A to Z, London - New York 2003, 290-291; Toussaint-Samat, Historia naturalna, s. 400-408.

${ }^{16}$ Por. Theodoretus, Historia religiosa XVII 6, PG 83, 1424; XXX 3, PG 83, 1493.

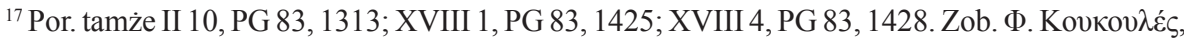

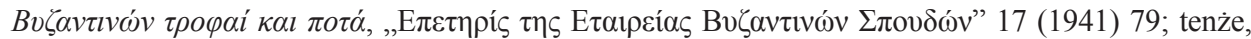

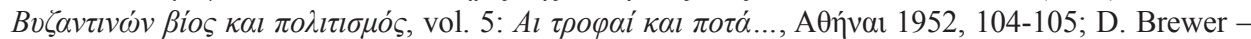
D.B. Redford - S. Redford, Domestic Plants and Animals. The Egyptians Origins, Warminster 1995, 51-52; M. Grant, Roman Cookery. Ancient Recipes for Modern Kitchens, London 2002, 92-95; Dalby, Food in the Ancient World, s. 143-144; J.P. Alcock, Food in the Ancient World, Westport - London 2006, 42-44; Rautman, Daily Life, s. 96; Toussaint-Samat, Historia naturalna, s. 605-609; Kokoszko, Smaki Konstantynopola, s. 531-532. Ze względu na dużą zawartość cukru, ciasno poukładane suszone figi mogły być przechowywane nawet przez kilka lat (por. L. Foxhall, Fig, w: The Oxford Classical Dictionary, ed. S. Hornblower - A. Spawforth - E. Eidinow, Oxford 2012, 575), co mogło mieć istotne znaczenie w klimacie, w jakim żyli syryjscy mnisi.

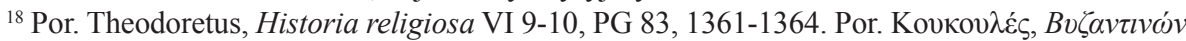

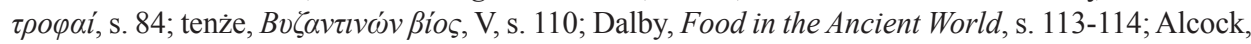
Food in the Ancient World, s. 41-42; Toussaint-Samat, Historia naturalna, s. 610-611. O korzyściach, jakie mnisi mogli czerpać z palmy daktylowej, poza spożywaniem jej owoców, w: Dembińska, Diet. A Comparison, s. 435-436.

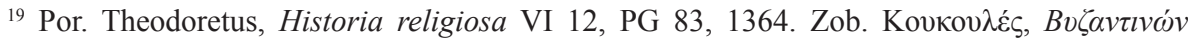

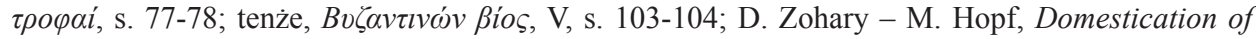
Plants in the Old Worlds. The Origin and Spread of Cultivated Plants in West Asia, Europe and the Nile Valley, Oxford 1993, 161-166; Dalby, Food in the Ancient World, s. 19-20; Alcock, Food in the 
ale nie uprawne, lecz dziko rosnące ${ }^{20}$. Niestety, biskup nie pozostawił nam bliższych informacji na ich temat. $Z$ jednego z żywotów dowiadujemy się, że

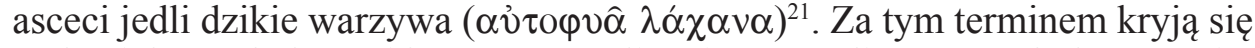
pędy niektórych drzew i krzewów, czyli $\beta \lambda \alpha ́ \sigma \tau \alpha$, rośliny zwane kolczastymi -

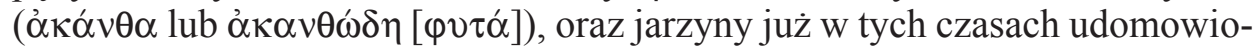
ne, ale nadal występujące również w dzikiej postaci, zbierane i powszechnie spożywane $^{22}$. W Historia religiosa wymienione zostają: sałata $(\theta \rho ı \delta \alpha \kappa i ́ v \eta)^{23}$,

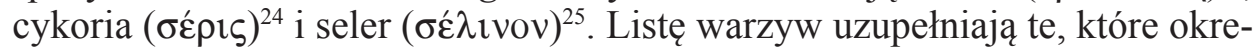
śla się mianem strączkowych, po grecku ő $\pi$ pı $\alpha$. Teodoret, ukazując żywot Macedoniusza, stwierdza, że nie żywił się on chlebem ani jarzynami strączkowymi, ale oczyszczonym jęczmieniem, który zmiękczał wodą ${ }^{26} . \mathrm{Z}$ wypowiedzi tej wynika, że ów asceta, po to, by uczynić swój dietetyczny rygor tym surowszym, odrzucił nawet owe ő $\pi \rho \imath \alpha$. Wobec tego zarówno one, jak i wymieniony obok nich chleb, musiały być jedzone przez innych mnichów. Sam

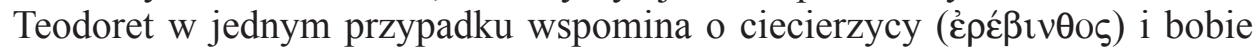

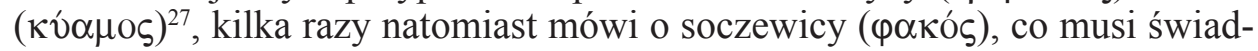
czyć o istotnym znaczeniu, jakie miała ona w jadłospisie świętych mężów. Z Dziejów dowiadujemy się, że tę ostatnią spożywali Acepsymas ${ }^{28}$, Jakub ${ }^{29}$,

Ancient World, s. 39; Rautman, Daily Life, s. 96; Toussaint-Samat, Historia naturalna, s. 563-569; Kokoszko, Smaki Konstantynopola, s. 533-534.

${ }^{20}$ Por. Theodoretus, Historia religiosa I 2, PG 83, 1293. Zob. tamże X 2, PG 83, 1389, gdzie mowa jest o tym, że mnich Teodozjusz uprawiał swój ogródek.

${ }^{21}$ Por. tamże II 4, PG 83, 1308.

${ }^{22}$ Por. Kokoszko - Gibel, Dieta mnichów syryjskich, s. 145-156.

${ }^{23}$ Por. Theodoretus, Historia religiosa XVII 6, PG 83, 1424; XXVI 7, PG 83, 1469. Zob. J. Koder, Gemüse in Byzanz. Die Versorgung Konstantinopels mit Frischgemüse im Lichte der Geoponika, Wien 1993, 36, 78, 95 i 97; Dalby, Food in the Ancient World, s. 195-196; Alcock, Food in the Ancient World, s. 55; Toussaint-Samat, Historia naturalna, s. 624-628; Kokoszko, Smaki Konstantynopola, s. 526-527; M. Kokoszko - K. Jagusiak, Warzywa w kuchni i dietetyce późnego antyku oraz wczesnego Bizancjum (IV-VII w.). Perspektywa konstantynopolitańska, „Piotrkowskie Zeszyty Historyczne” 12 (2011) 45-46.

${ }^{24}$ Por. Theodoretus, Historia religiosa XVII 6, PG 83, 1424; XXVI 7, PG 83, 1469. Zob. Koder, Gemüse in Byzanz, s. 82, 86 i 90; Dalby, Food in the Ancient World, s. 132; Toussaint-Samat, Historia naturalna, s. 628-630.

${ }^{25}$ Por. Theodoretus, Historia religiosa XVII 6, PG 83, 1424. Zob. E.L. Sturtevant, History of Celery, „The American Naturalist” 20 (1886) 599-606; A.C. Andrews, Celery and Parsley as Foods in the Greco-Roman Period, CPh 44 (1949) fasc. 2, 91-99; Koder, Gemüse in Byzanz, s. 15, 36 i 89; Dalby, Food in the Ancient World, s. 77-78; Alcock, Food in the Ancient World, s. 50; Kokoszko, Smaki Konstantynopola, s. 519-520; Kokoszko - Jagusiak, Warzywa w kuchni, s. 38-39.

${ }^{26}$ Por. Theodoretus, Historia religiosa XIII 3, PG 83, 1401.

${ }^{27}$ Por. tamże XVIII 1, PG 83, 1425 (w polskim thumaczeniu terminy te oddano, odpowiednio, jako groch i fasola, ŹM 7, 214).

${ }^{28}$ Por. tamże XV 1, PG 83, 1416.

${ }^{29}$ Por. tamże XXI 12, PG 83, 1437-1440. 
Damian $^{30}$ i ascetka Domnina ${ }^{31}$. Pojawia się ona również w żywocie Publiusza, gdzie czytamy, że święty Aftonios zajmował się czyszczeniem jej ziarna ${ }^{32}$. Wiemy, że jeśli tylko było to możliwe, mnisi rezygnowali z poddawania warzyw jakiejkolwiek obróbce termicznej ${ }^{33}$ i zastępowali ją moczeniem ${ }^{34}$. Praktyka ta odnosiła się także do soczewicy, a dowodzi tego każdy z przywołanych wyżej fragmentów, który przekazuje informację o jej konsumpcji.

Analiza fragmentu innej pracy napisanej przez Teodoreta, człowieka bardzo dobrze wykształconego ${ }^{35}$, pozwala nam sądzić, że mógł on poszczycić się posiadaniem między innymi fachowej wiedzy medycznej ${ }^{36}$. W dziele $O \mathrm{mi}$ łości Bożej biskup chwali bowiem syryjskich mnichów i wylicza trudy ich życia. Za jeden z nich uznaje dietę, którą stosowali, a poświęcając jej kilka słów, dowodzi swojej znajomości ówczesnych teorii dotyczących funkcjonowania układu pokarmowego człowieka. Idąc za Galenem ${ }^{37}$, pisze, że trawione jedzenie przechodzi do wątroby, gdzie zamienia się $\mathrm{w} \mathrm{krew}^{38}$. Teodoret wie, że to nie ogień czy odzież a właśnie pokarm dostarcza ludzkiemu ciału ciepło. Biorąc to pod uwagę, powątpiewa w wartość, jaką będą miały ciepło

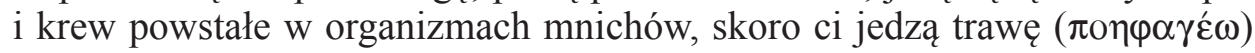

${ }^{30}$ Por. tamże XXIV 5, PG 83, 1459-1460.

${ }^{31}$ Por. tamże XXX 2-3, PG 83, 1493.

${ }^{32}$ Por. tamże V 8, PG 83, 1356.

${ }^{33}$ Por. tamże I 2, PG 83, 1293; III 21, PG 83, 1337; XVII 6, PG 83, 1424; XXI 11, PG 83, 1437.

${ }^{34}$ Por. np. tamże XVIII 1, PG 83, 1425 - mowa o ciecierzycy i bobie. Podobnie postępowano z mąką (por. tamże III 21, PG 83, 1337) i jęczmieniem (por. tamże XIII 3, PG 83, 1401).

${ }^{35}$ Por. Pasztori-Kupan, Theodoret, s. 4.

${ }^{36}$ Dowodem bardzo dobrej znajomości problematyki medycznej jest również fakt, iż związane z nią metafory Teodoret wykorzystywał często jako pomoc w argumentowaniu kwestii teologicznych, por. V. Nutton, Ancient Medicine, New York - London 2004, 302.

${ }^{37}$ Galen (ok. 130 - ok. 200/210) to jeden z najwybitniejszych lekarzy starożytności, który pozostawił po sobie olbrzymią spuściznę literacką (w niepełnej edycji C.G. Kühna liczy ona ok. 10 tys. stron). W swoich dziełach o tematyce medycznej, pisał bowiem także traktaty filozoficzne, poruszał różnorodne kwestie, wśród których znalazły się również dotyczące dietetyki. Por. m.in. L. Thorndike, Galen. The Man and His Times, „The Scientific Monthly” 14 (1922) 83-93; G. Sarton, Galen of Pergamon, Lawrence 1954; L.H. Toledo-Pereyra, Galen's Contribution to Surgery, „Journal of the History of Medicine and Allied Sciences" 28 (1973), 357-375; L.T. Pearcy, Galen and Stoic Rhetoric, GRBS 24 (1983) 259-272; A. Bednarczyk, System filozoficzno-lekarski Galena (130-200). Pojęcie ciepła przyrodzonego i pneumy życiowej, „Analecta. Studia i Materiały z Dziejów Nauki” 2 (1993) 53-111; M. Grant, Introduction, w: Galen, On Food and Diet, transl. M. Grant, London 2000, 1-6; Kokoszko, Ryby i ich znaczenie, s. 12-13; R.J. Hankinson, Galen of Pergamon, w: The Encyclopedia of Ancient Natural Scientists. The Greek Tradition and its Many Heirs (= EANS), ed. P. Keyser - G.L. Irby-Massie, Milton Park - New York 2008, 335-339.

${ }^{38}$ Por. O. Temkin, Galenism. Rise and Decline of a Medical Philosophy, Ithaca - London 1973, 154-156; Nutton, Ancient Medicine, s. 233. Galen nie formułuje swoich poglądów na temat procesu trawienia jako spójnej teorii, by je poznać należy przestudiować cały korpus jego tekstów. Zob. B.J. Good, Medicine, Rationality and Experience. An Anthropological Perspective, Cambridge 1994, 103-106; Grant, Introduction, w: Galen, On Food, s. 7-8; P. Prioreschi, A History of Medicine, vol. 3: Roman Medicine, Omaha 2001, 420-424. 
lub rozmiękczone w wodzie jarzyny strączkowe - ó $\sigma \pi \rho \alpha^{39}$. Prawdopodobne jest zatem, że celowe unikanie przez ascetów termicznej obróbki żywności mogło łączyć się z teorią sformułowaną choćby przez lekarza z Pergamonu, która głosiła, że jedzenie ulega w żołądku procesowi podobnemu do gotowania ${ }^{40}$. Wydaje się, że bohaterowie Historia religiosa nie musieli opierać się wyłącznie na własnych doświadczeniach, jakimi były przykre dla ich samopoczucia i zdrowia skutki spożywania tego typu pokarmu, ale mogli także znać treść traktatów medycznych i w swoim postępowaniu kierować się zawartą w nich nauką. Jak pokazaliśmy, znał ją Teodoret, który zanim został biskupem sam uprawiał ascezę, później natomiast pozostawał w stałym kontakcie ze świętymi mężami. Mnisi, którzy w imię wyznawanej wiary gotowi byli do wszelkich poświęceń, nie chcieli ułatwiać i przyspieszać procesu trawienia, jaki zachodził $w$ ich organizmach. $Z$ tego powodu sięgali po surowe produkty lub, jak to miało miejsce w przypadku soczewicy, jedynie je zmiękczali poprzez namaczanie ${ }^{41}$.

Awersja ascetów do poddawania spożywanych warzyw procesowi gotowania mogła wynikać również z chęci zaoszczędzenia czasu, po to, by móc w pełni poświęcić go na modlitwę. Innego wytłumaczenia powodu takiego zachowania dostarcza współczesna antropologia kulturowa. Jeden z jej czołowych przedstawicieli, Claude Lévi-Strauss, uważał, że gotowanie jedzenia jest w dwójnasób utożsamiane z kulturą - po pierwsze realnie, ponieważ wymaga użycia naczynia będącego jej wytworem, po drugie symbolicznie, gdyż wykorzystuje wodę, a ta, podobnie jak kultura pośrednicząca w stosunkach między człowiekiem a światem zewnętrznym, jest tym, co w trakcie warzenia znajduje się między pokarmem a ogniem ${ }^{42}$. Dowodów na identyfikowanie ugotowanego jedzenia ze wszystkim, co wiąże się z kulturą i cywilizacją, surowego zaś z ich przeciwieństwami dostarcza literatura antyczna, w tym także

\footnotetext{
${ }^{39}$ Por. Theodoretus, Oratio de divina et sancta charitate 2, PG 83, 1497-1500.

${ }^{40}$ Por. Galenus, De naturalibus facultatibus 160, 17 - 168, 5 (w niniejszym opracowaniu posłużono się wydaniem: Claudii Galeni Opera omnia, ed. D.C.G. Kühn, vol. 2, Lipsiae 1821). Galen szydzi tutaj z Erasistratosa, lekarza greckiego żyjącego w IV-III w. prz. Chr. (por. P.M. Fraser, The Career of Erasistratus of Ceos, „Istituto Lombardo. Rendiconti” 103 (1969) 518-537; W.D. Smith, Erasistratus's Dietetic Medicine, „Bulletin of the History of Medicine” 56 (1982) 398-409; J. Scarborough, Erasistratos of Ioulis on Keos, EANS 294-296), który nie wierzył, że jedzenie może zostać ugotowane za sprawą ciepła, jakie panuje w żołądku; por. Galenus, De usu partium 275, 3 - 281, 19 (posłużono się wydaniem: Claudii Galeni Opera omnia, ed. D.C.G. Kühn, vol. 3-4, Lipsiae 1822). Zob. Mazzini, Diet and Medicine, s. 143 oraz uwagi M.J. Schiefskyego (Commentary, w: Hippocrates, On Ancient Medicine, transl., introd., comm. M.J. Schiefsky, Leiden - Boston 2005, 316-317) dotyczące poglądów Hipokratesa na ten temat.

${ }^{41}$ Starożytni lekarze byli zdania, iż gotowane jedzenie jest nie tylko łatwiej trawione przez organizm, ale i zdrowsze dla człowieka, por. Mazzini, Diet and Medicine, s. 145 i 148-149.

${ }^{42}$ Por. C. Lévi-Strauss, Trójkąt kulinarny, przeł. S. Ciechowicz, „Twórczość” (1972) nr 2, 73. Zob. tenże, Surowe i gotowane, przeł. M. Falski, Warszawa 2010; E. Leach, Levi-Strauss, tłum. P. Niklewicz, Warszawa 1973, 22-39.
} 
traktaty medyczne ${ }^{43}$. Analizowane postępowanie mnichów mogło zatem być jedną z form zamanifestowania swojej odrębności od świata, którego pokusy oddalały od Boga ${ }^{44}$.

\section{Rośliny strączkowe w epoce starożytnej i wczesnobizantyńskiej.} Rośliny strączkowe, do których zaliczamy soczewicę, od tysiącleci stanowiły istotny składnik diety osób zamieszkujących tereny położone nad Morzem Sródziemnym. W rankingu ilości spożycia stały zapewne na drugim miejscu, tuż za roślinami zbożowymi. Znano wiele ich gatunków i powszechnie je uprawiano, co sprawiało, że nie były one zbyt kosztownym towarem. Stanowiły zatem pokarm popularny, ale nie ceniony równie wysoko jak produkty otrzymywane ze zbóż ${ }^{45}$. Przyczyna zaniżenia wystawianej im oceny wynikała z faktu, iż mąka ő $\lambda \varepsilon v \rho o v$, jaką z nich uzyskiwano, nie nadawała się do produkcji chleba. Ponadto, charakterystyka dietetyczna ǒ $\sigma \rho \imath \alpha$ wskazywała na ich niekorzystne cechy, zwłaszcza na wiatropędność, a nawet na szkodliwy wpływ na zdrowie. Niektóre spośród roślin strączkowych, jak choćby łubin ${ }^{46}$ czy wyka ${ }^{47}$, uznawano wręcz za pokarm, po który warto było sięgać tylko w przypadku nastania głodu. Choć w pismach późnoantycznych i bizantyńskich lekarzy, jak prześledzimy to na przykładzie soczewicy, ő $\sigma \pi \rho \imath \alpha$ nie cieszyły się zbyt dobrą opinią, to ich charakterystyce poświęcono tam stosunkowo dużo uwagi. $Z$ jednej strony świadczy to o tym, że liczba osób, które chciały lub też musiały oprzeć swoją dietę na tego rodzaju produktach, była na tyle wysoka, że medycy poczuli się zmuszeni do zanalizowania tego zjawiska i uprzedzenia czytelników swoich pism o negatywnych skutkach takich nawyków żywieniowych. Z drugiej strony, złe opinie na temat roślin strączkowych nie przeszkodziły wykorzystywaniu niektórych z nich jako $\varphi \alpha ́ \rho \mu \alpha \kappa \alpha$, czyli medykamentów, co dodatkowo umocniło pozycję tych warzyw wśród roślin wartych uprawy.

${ }^{43}$ Por. Ch. Segal, The Raw and the Cooked in Greek Literature. Structure, Values, Metaphor, „The Classical Journal” 69 (1974) 289-308 (spec. 298-301).

${ }^{44}$ Por. M. Montanari, Food is Culture, transl. A. Sonnenfeld, New York - Chichester 2006, 43-44.

${ }^{45}$ Por. A. Dalby, Siren Feasts. A History of Food and Gastronomy in Greece, London 1996, 39; K.B. Flint-Hamilton, Legumes in Ancient Greece and Rome: Food, Medicine, or Poison?, „Hesperia” 68 (1999) 372-375; P. Garnsey, Food and Society in Classical Antiquity, Cambridge 1999, 15; Dalby, Flavours of Byzantium, s. 194; Kokoszko, Smaki Konstantynopola, s. 485; M. Kokoszko - Ł. Erlich, Rola roślin straczkowych (ospria) w diecie późnego antyku i wczesnego Bizancjum (IV-VII w.) na podstawie wybranych źródet, „Zeszyty Wiejskie” 17 (2012) 8. Zob. L. Foxhall - H.A. Forbes, Sitomereia. The Role of Grain as Staple Food in Classical Antiquity, „Chiron” 12 (1982) 41-90.

${ }^{46}$ Por. P. Garnsey, Famine and Food Supply in the Graeco-Roman World. Responses to Risk and Crisis, Cambridge 1989, 52. O łubinie m.in. w: Dalby, Food in the Ancient World, s. 201.

${ }^{47}$ Por. Garnsey, Food and Society, s. 37-38. O wyce m.in. w: Zohary - Hopf, Domestication of Plants, s. 110-114; Flint-Hamilton, Legumes in Ancient Greece and Rome, s. 378-379; Dalby, Food in the Ancient World, s. 342-343; Kokoszko - Erlich, Rola roślin straczkowych, s. 16-17. 
Analiza treści traktatów medycznych pozwala twierdzić, że z upływem czasu wspomniane tendencje nie uległy zmianom. Odnośnie do ery wczesnego Bizancjum i okresu późniejszego potwierdzają to najnowsze wyniki badań takich specjalistów, jak Phedon Koukoules ${ }^{48}$, Johannes Koder ${ }^{49}$ oraz Marcus Louis Rautman ${ }^{50}$. Badacze ci uważają, że ő $\sigma \pi \rho \alpha \mathrm{w}$ dalszym ciągu stanowiły pokarm o podstawowym znaczeniu, który jednak nadal nie przewyższał swoją rangą roślin zbożowych ${ }^{51}$. Cały czas również, nie bacząc na ich niezbyt pozytywną ocenę dietetyczną, wykorzystywano je jako surowiec kulinarny. Traktat $O$ sztuce gospodarowania poświęca bowiem ogólnym zasadom gotowania roślin strączkowych cały rozdział ${ }^{52} \mathrm{i}$ w ten sposób dowodzi ich wagi w rolnictwie i gastronomii pomiędzy VI a X w. Rady, jakie znajdujemy w tym dziele, są dość proste i praktyczne, a te, które odnoszą się do kwestii przyrządzania ǒ $\pi \rho \imath \alpha$, zalecają gotowanie ich z dodatkiem gorczycy. To ona, dołożona w odpowiedniej ilości, sprawi, że soczewica, groch czy inne produkty z tej grupy szybko się rozgotują, tworząc jednolitą papkę będącą doskonałą podstawą do przyrządzenia zupy, a więc najczęstszej formy serwowania omawianych produktów $w^{53}$. Gorczyca przyczyniała się tutaj nie tylko do przyspieszenia procesu mięknięcia ő $\sigma \rho \alpha^{54}$, ale także do zredukowania ich wiatropędności. Warto zauważyć, że sugestie autora Geoponica uzupełniają rozważania dietetyczno-kulinarne zawarte w pismach medycznych. Świadczy to o powszechności doktryn żywieniowych poza obszarem zainteresowania materia medica. Ponadto, skoro źródłem informacji zawartych w O sztuce gospodarowania jest Demokryt, to możemy się domyślać, że

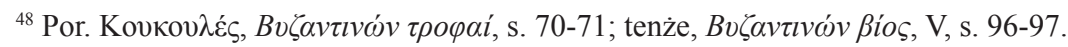

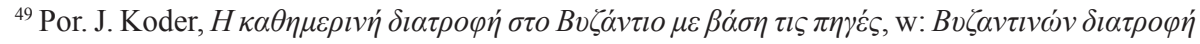

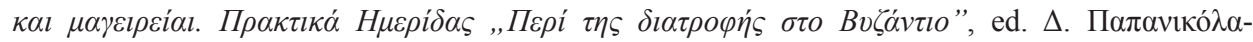

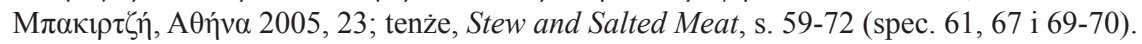

${ }^{50}$ Por. Rautman, Daily Life, s. 252.

${ }^{51}$ Por. L. Garland, The Rhetoric of Gluttony and Hunger in Twelfth-century Byzantium, w: Feast, Fast or Famine. Food and Drink in Byzantium, ed. W. Mayer - S. Trzcionka, Brisbane 2005, 48 (opinia na temat bobu).

${ }^{52}$ Por. Cassianus Bassus, Geoponica II (w niniejszym artykule posłużono się wydaniem: Geoponica sive Cassiani Bassi Scholastici de re rustica eclogue, rec. H. Beckh, Lipsiae 1895). Przywołane tutaj Geoponica to bizantyńska encyklopedia rolnicza, której pierwsza edycja przypisywana jest Kassianusowi Bassusowi Scholastykowi, żyjącemu w VI w. Wersja, którą dysponujemy dzisiaj, to tekst ponownie zredagowany w X w., za czasów Konstantyna VII Porfirogenety. Dzieło

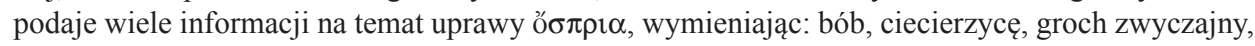
groszek zwyczajny, kozieradkę, lucernę, łubin, soczewicę, wykę siewną oraz wykę soczewicowatą. Więcej na temat Geoponica m.in. w: J.L. Teall, The Byzantine Agricultural Tradition, DOP 25 (1971) 35-59; I. Mikołajczyk, Wstęp, w: Kassianus Bassus, Geoponika. Bizantyńska encyklopedia rolnicza, przeł., wstęp I. Mikołajczyk, Torun 2012, 7-45.

${ }^{53}$ Por. Cassianus Bassus, Geoponica II 41.

${ }^{54}$ Autor wskazuje, że gorczyca działała w podobny sposób również na mięso. Por. M. Kokoszko, Aromaty kuchni antyku oraz wczesnego Bizancjum w teorii medycznej i praktyce kulinarnej, „Przegląd Historyczny” 102 (2011) 553-554.
} 
już w czasach, gdy ów filozof działał, greckojęzyczna ludność obszaru śródziemnomorskiego praktykowała gotowanie jarzyn strączkowych z dodatkiem gorczycy, a następnie pamiętała o tym sposobie co najmniej do momentu, w którym wydano to ciekawe dzieło agronomiczne, czyli do X w.

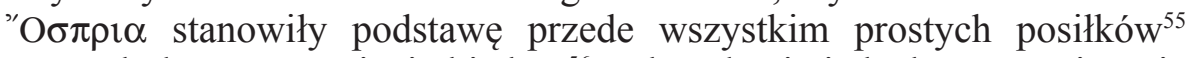
i uważane były za pożywienie biedoty ${ }^{56}$. Zdarzało się jednak, że czyniono je składnikami bardziej lub nawet bardzo wyszukanych dań ${ }^{57}$. Wraz ze schyłkiem antyku nie tylko nie nastąpił kres wykorzystywania ich do przyrządzania luksusowych potraw ${ }^{58}$, ale wręcz zyskały one na popularności. Przyczyna tego stanu tkwiła, jak twierdzą Athanasius Louvaris ${ }^{59}$ i Andrew Dalby ${ }^{60}$, w wydawanych przez Kościół nakazach i zakazach dotyczących diety chrześcijan, a zwłaszcza we wprowadzaniu długotrwałych okresów postu, które zmuszały kucharzy do szczególnej kreatywności w tworzeniu bezmięsnego menu. Na wykwintne potrawy z jarzyn strączkowych stać było jednak wyłącznie ludzi zamożnych. Większość społeczeństwa traktowała je jako typowy pokarm postny ${ }^{61}$, wielu nie mogło pozwolić sobie na to, by doprawiać je w wytworny sposób $^{62}$. Najbardziej gorliwi asceci, jak choćby mnisi, o których opowiada Teodoret z Cyru, rezygnowali nawet $\mathrm{z}$ wydawałoby się koniecznych dodatków do gotowanej soczewicy, fasoli czy grochu ${ }^{63}$.

${ }^{55}$ Ze źródeł medycznych wynika jednak, iż zawsze istniały także bardziej wyszukane wersje

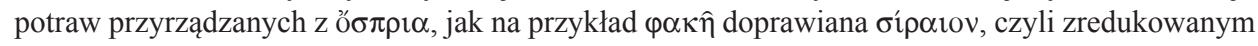
moszczem winnym, o której wspomina choćby Galen.

${ }^{56}$ Por. M. Corbier, The Broad Bean and the Moray. Social Hierarchies and Food in Rome, w: Food. A Culinary History, s. 132-135; J. Wilkins, The Boastful Chef. The Discourse of Food in Ancient Greek Comedy, Oxford 2000, 13-16.

${ }^{57}$ Por. A. Dalby, Tastes of Byzantium. The Cuisine of a Legendary Empire, London 2010, 80-81. Przepisy na tego typu dania podaje m.in. datowany na przełom IV i V w. po Chr. traktat $O$ sztuce kulinarnej, którego autorstwo przypisywane jest niejakiemu Apicjuszowi - Apicius, De re coquinaria V 3, 2 (w niniejszym opracowaniu posłużono się wydaniem: Apicius, A Critical Edition with an Introduction and an English Translation of the Latin Recipe Text Apicius, Text and Commentary Ch. Grocock - S. Grainger, Totnes 2006). P. Garnsey (Food and Society, s. 121) zauważa jednak, że dla osób bogatych, w przeciwieństwie do biedoty, włączenie roślin strączkowych do menu nie było koniecznością, a jedynie wyborem. Na temat De re coquinaria por. H. Lindsay, Who Was Apicius?, SO 72 (1997) 144-154; Kokoszko, Ryby i ich znaczenie, s. 19-20; S. Grainger, The Myth of Apicius, „Gastronomica. The Journal of Food and Culture” 7 (2007) fasc. 2, 71-77; S. Wyszomirski, Wstęp, w: Apicjusz, O sztuce kulinarnej. Ksiagg dziesięć, tłum. I. Mikołajczyk - S. Wyszomirski, Toruń 2012, 3-17.

${ }^{58}$ Por. Dalby, Flavours of Byzantium, s. 80.

${ }^{59}$ Por. A.N.J. Louvaris, Fast and Abstinence in Byzantium, w: Feast, s. 196.

${ }^{60}$ Por. Dalby, Flavours of Byzantium, s. 80.

${ }^{61}$ Por. K. Parry, Vegetarianism in Late Antiquity and Byzantium. The Transmission of a Regimen, w: Feats, s. 184.

${ }^{62}$ Por. Talbot, Mealtime in Monasteries, s. 118.

${ }^{63}$ Por. Louvaris, Fast and Abstinence in Byzantium, s. 192. 


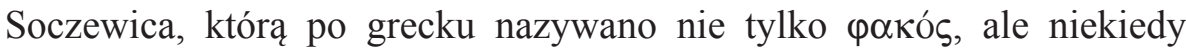
również $\varphi \alpha \kappa \hat{\eta}$, była $\mathrm{w}$ starożytności i $\mathrm{w}$ okresie wczesnobizantyńskim jedną z najbardziej popularnych, ponieważ najszerzej rozpowszechnionych roślin strączkowych. Na terenach syryjskich wykorzystywano ją jako pokarm już przed dwunastym tysiącleciem prz. Chr., zaś na obszarach zamieszkanych przez Greków czyniono to od siódmego tysiąclecia prz. Chrystusem ${ }^{64}$. Pisma pochodzące ze starożytności poświadczają, że z upływem czasu stała się ona dla ludzi tej epoki jednym z podstawowych źródeł węglowodanów i białka roślinnego. Rosnącego znaczenia soczewicy dowodzi fakt, iż była ona tematem często podejmowanym przez litterati antyku ${ }^{65}$, a następnie Bizancjum ${ }^{66}$. Za jej popularnością, tak jak w przypadku innych ó $\sigma \pi \rho \imath \alpha$, stała przede wszystkim niska cena. Atenajos z Naukratis zachował powiedzenie: „dodawać mirry do zupy z soczewicy" ${ }^{67}$, które oznaczało, że kosztowną mirrą lub cennym olejkiem mirrowym nie powinno się doprawiać taniej i mało wyszukanej potrawy, jaką zwykle, w swojej podstawowej wersji, było pożywienie, o którym mowa. Przyjrzyjmy się zatem soczewicy szczegółowo, omawiając jej ocenę dietetyczną oraz medyczne i kulinarne zastosowanie, jakie prezentują źródła, które wybraliśmy do analizy.

3. Właściwości dietetyczne soczewicy. Antyk i Bizancjum pozostawiły

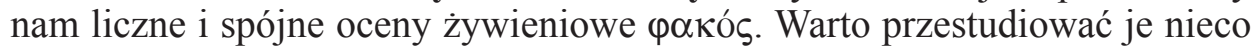
uważniej, by móc ukazać ciągłość doktryn dietetycznych w interesującym nas okresie. Dioskurides ${ }^{68}$ informował więc o właściwościach soczewicy z deta-

${ }^{64}$ Por. Flint-Hamilton, Legumes in Ancient Greece and Rome, s. 375-377; L. Kaplan, Beans, Peas and Lentils, w: The Cambridge World History of Food, vol. 1, ed. K.F. Kiple - K.C. Ornelas, Cambridge - New York 2000, 277-279; Dalby, Food in the Ancient World, s. 194; Alcock, Food in the Ancient World, s. 36-37; Toussaint-Samat, Historia naturalna, s. 42; Kokoszko - Erlich, Rola roślin straczkowych, s. 13-16.

${ }^{65}$ Pisze o niej m.in. Atenajos z Naukratis w swoim monumentalnym dziele zatytułowanym Deipnosofiści. Utwór powstał w latach 20. lub 30. III w. po Chr. Ma formę dialogu traktującego o szeroko rozumianej sztuce kulinarnej i stanowi podstawowe źródło podsumowujące wiedzę antyku na temat gastronomii (por. Kokoszko, Ryby i ich znaczenie, s. 10-12; J. Wilkins, Athenaeus the Navigator, „The Journal of Hellenic Studies” 128 (2008) 132-152; K. Bartol - J. Danielewicz, Wstep, w: Atenajos, Uczta mędrców, przeł., wstęp, koment. K. Bartol - J. Danielewicz, Poznań 2012², 7-64; J. Paulas, How to Read Athenaeus ', Deipnosophists”, „The American Journal of Philology” 133 (2012) 403439) - Athenaeus Naucratita, Deipnosophistae IV 156c - 160c (44, 21 - 51, 18, Kaibel - w niniejszym opracowaniu korzystano z wydania: Athenaei Naucratitae Dipnosophistarum libri XV, rec. G. Kaibel, vol. 1-3, Lipsiae - Berolini 1887-1890). Por. Zohary - Hopf, Domestication of Plants, s. 88-94.

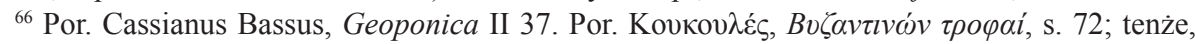

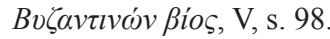

${ }^{67}$ Athenaeus Naucratita, Deipnosophistae IV 160c (51, 13, Kaibel).

${ }^{68}$ Dioskurides, żyjący w I w. po Chr., był greckim farmakologiem. Jego praca, której łaciński tytuł brzmi De materia medica, poświęcona została roślinnym środkom leczniczym (choć nie pomija leków pochodzenia zwierzęcego i mineralnego, a nawet środków magicznych) i w sposób niezwykle szczegółowy opisuje ok. sześśset roślin. Dzieło to wyparło całą wcześniejszą literaturę 
lami, różnicując jej charakterystykę w zależności od metody przyrządzania tego pokarmu. Rozpoczynając rozdział omawiający rzeczoną roślinę, autor

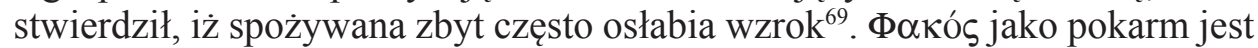
trudna do wstępnego strawienia w żołądku, ponadto napełnia go, jak i całe wnętrzności, gazami ${ }^{70}$. Z treści rozdziału wnosić wypada, iż za istotną cechę dietetyczną soczewicy uznawano powodowanie przez nią zatrzymania pracy systemu trawiennego, do którego dochodzi wówczas, gdy gotowana jest wraz $\mathrm{z}$ łuską ${ }^{71}$. Wynika to $\mathrm{z}$ faktu, iż ta ostatnia ma właściwości ściągające, co sprawia, że pokarm ten, po uprzednim obraniu z łusek i starannym ugotowaniu (przy odlaniu pierwszej wody, w której poddany był działaniu temperatury ${ }^{72}$ ), wywołuje zatrzymanie wydalania ${ }^{73}$. Inne właściwości ma soczewica, która w trakcie obróbki termicznej nie wypuszcza już ciemnego barwnika. Wywar powstały w wyniku jej odgotowania - do którego, jak należy rozumieć, przeszły właściwości soku - doprowadza bowiem do przeczyszczenia ${ }^{74}$. Soczewica, kontynuował Dioskurides, sprowadza nadto złe sny ${ }^{75}$ i osłabia twarde tkanki ciała, płuca oraz głowę ${ }^{76}$.

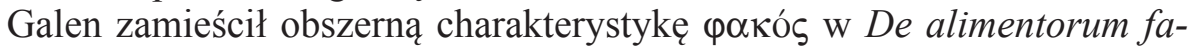
cultatibus $^{77}$. Stanowi ona twórczą kontynuację rozważań Dioskuridesa, ale dodatkowo, w wielu punktach, pogłębia naszą wiedzę na ten temat. Lekarz stwierdził wpierw, że soczewica nie posiada elementu łączącego $\mathrm{w}$ jedno strukturę wnętrza jej ziaren i dlatego jest niespójna wewnętrznie ${ }^{78}$. Warto tutaj dodać, iż ta jej właściwość czyniła ją niezdatną do wypieku chleba - ciasto wyrobione z mąki gorczycznej nie kleiło się i nie miało szansy na wyrośnięcie. Medyk z Pergamonu utrzymywał ponadto, iż łuska otaczająca ziarna soczewicy, na którą zwracał uwagę również jego poprzednik, jest ściągająca ${ }^{79}$, natomiast substancja, z której składają się ziarna, przyczynia się do powstawania gęstych soków ${ }^{80}$, jest ziemista, z niewielkim tylko udziałem cierpkości

z tej dziedziny i długo cieszyło się dużą popularnością. Por. Kokoszko, Ryby i ich znaczenie, s. 12; J. Scarborough, Dioskourides of Anazarbos, EANS 271-273.

${ }^{69}$ Por. Dioscurides Pedanius, De materia medica II 107, 1, 1 (w niniejszym artykule posłużono się wydaniem: Pedanii Dioscuridis Anazarbei De materia medica libri quinque, ed. M. Wellmann, vol. 1-3, Berolini 1906-1914).

${ }^{70}$ Por. tamże II 107, 1, 1-2.

${ }^{71}$ Por. tamże II 107, 1, 2-3.

${ }^{72}$ Por. tamże II 107, 1, 6.

${ }^{73}$ Por. tamże II 107, 1, 3-6.

${ }^{74}$ Por. tamże II 107, 1, 6-7.

${ }^{75}$ Por. tamże II 107, 1, 7

${ }^{76}$ Por. tamże II 107, 1, 7-2, 1.

${ }^{77}$ Galenus, De alimentorum facultatibus 525, 6-525, 16 (w niniejszym opracowaniu posłużono się wydaniem: Claudii Galeni Opera omnia, ed. D.C.G. Kühn, vol. 6, Lipsiae 1823).

${ }^{78}$ Por. tamże $525,7$.

${ }^{79}$ Por. tamże $525,8$.

${ }^{80}$ Antyczna i bizantyńska nauka o roli pokarmu w życiu człowieka opierała się na tak zwanej teorii czterech humorów ( $\chi \cup \mu o u ́)$, czyli soków organicznych. Były nimi: krew, żółć, czarna żółć 
(właściwej dla łuski) ${ }^{81}$. Sok ( $\chi v \lambda o ́ \varsigma$ ) obecny w soczewicy reprezentuje z kolei cechy przeciwne do ściągających, a wywar powstały w wyniku jego przejścia do wody w czasie gotowania $\varphi \alpha \kappa o ́ s$, odpowiednio przyprawiony sosem rybnym i oliwą, przeczyszcza przewód pokarmowy ${ }^{82}$. Zupa $\varphi \propto \kappa \hat{\eta}^{83}$ przyrządzana z soczewicy ma działanie odwrotne niż jej sok, gdyż wysusza nadmiar soków znajdujących się w żołądku i działa tonizująco nie tylko na ten narząd, ale i na cały przewód pokarmowy ${ }^{84}$. Soczewica po zdjęciu z niej łuski traci silne własności ściągające, dodatkowo staje się bardziej pożywna, jeszcze efektywniej powoduje też powstawanie gęstych soków, wolniej przechodzi przez organizm, choć jej zdolności do wysuszania tracą na intensywności ${ }^{85}$. Galen przestrzegał przed spożywaniem jej w zbyt dużych ilościach, gdyż doprowadza ona do powstania melancholicznych soków, a przez to do utraty zdrowia ${ }^{86}$. Ten rodzaj soków uznawano bowiem za najniebezpieczniejszy dla człowieka.

Zatem, z uwagi na swoje właściwości, soczewica jest dobra dla tych, którzy z natury mają wilgotną strukturę ciała, zaś szkodzi tym, którzy są wysuszeni ${ }^{87}$. Ponieważ $\varphi \propto \kappa \hat{n}$ przyczynia się do powstawania soków gęstych i melancholicznych, prowadząc do zakłócenia równowagi humoralnej, trzeba ograniczyć jej spożycie w czasie gorąca i braku wilgoci, a więc zawłaszcza w okresie po zbiorach ( $\varphi$ Өvó $\pi \omega \rho \circ v)$, za to jeść ją zimą ${ }^{88}$.

Dodać należy, że w De simplicium medicamentorum temperamentis ac facultatibus znajdujemy charakterystykę soczewicy sporządzoną pod kątem oceny jej cech farmakologicznych ${ }^{89}$. Niewiele jednak odbiega ona od tego, co stało się podstawą treści rozdziału De alimentorum facultatibus. W pierwszym z wymienionych dzieł Galen twierdzi bowiem, iż soczewica ma silne właściwości ściągające ${ }^{90}$, natomiast pod względem działania rozgrzewającego lub oziębiającego plasuje się centralnie między dwiema skrajnymi warto-

i flegma. Od właściwej proporcji zmieszania owych humorów oraz od zachowania ich cech charakterystycznych (tj. wilgoci, suchości, ciepła i zimna) w stanie pierwotnym miało zależeć zdrowie człowieka. Por. J. Jouanna, La théorie des quatre humeurs et des quatre tempéraments dans la tradition latine (Vindicien, Pseudo-Soranos) et une source grecque retrouvée, REG 118 (2005) fasc. 1, 138167; N. Arikha, Passions and Tempers. A History of the Humours, New York 2007, 3-47; J. Bos, The Rise and Decline of Character. Humoral Psychology in Ancient and Early Modern Medical Theory, „History of the Human Sciences” 22 (2009) fasc. 3, 29-50; Kokoszko - Rzeźnicka, Dietetyka w De re coquinaria, s. 8-10.

${ }^{81}$ Por. Galenus, De alimentorum facultatibus 525, 8-10.

${ }^{82}$ Por. tamże 525, 10-13.

${ }^{83}$ Por. tamże 525, 14.

${ }^{84}$ Por. tamże 525, 13-16.

${ }^{85}$ Por. tamże $525,1-5$.

${ }^{86}$ Por. tamże 526, 5-8.

${ }^{87}$ Por. tamże 526, 9-11.

${ }^{88}$ Por. tamże 528, 3-12.

${ }^{89}$ Por. tenże, De simplicium medicamentorum temperamentis ac facultatibus 149, 5-10 (posłużono się wydaniem: Claudii Galeni Opera omnia, ed. D.C.G. Kühn, vol. 11-12, Lipsiae 1826-1827).

${ }^{90}$ Por. tamże 149, 5-6. 
ściami, co sprawia, że w praktyce jest pokarmem neutralnym ${ }^{91}$. Drugą, co do stopnia oddziaływania na organizm człowieka cechą soczewicy jest, według naszego medyka, osuszanie. Sama materia $\varphi \propto \kappa \hat{\eta}$ wysusza ciało i spowalnia pracę przewodu pokarmowego ${ }^{92}$. Z kolei wywar powstający w wyniku poddania jej obróbce termicznej sprzyja przeczyszczeniu ${ }^{93}$, dlatego też, chcąc temu zapobiec, odlewa się pierwszą wodę z jej gotowania ${ }^{94}$.

Kolejny z lekarzy, którego poglądy chcemy zaprezentować, mianowicie Orybazjusz $^{95}$, podobnie jak Galen, uznał $\varphi \alpha \kappa \hat{\eta}^{96}$ i soczewicę ${ }^{97}$ za jedzenie melancholiczne ${ }^{98}$. Ów medyk kategoryzował też tę pierwsząa9 jako bardzo pożywną ${ }^{100}$. Ponadto, zaliczył tę potrawę ${ }^{101}$ do grupy pokarmów o zakłóconej równo-

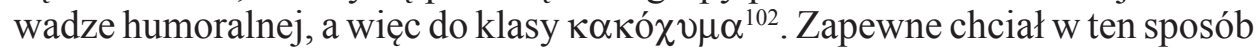
wskazać na fakt, iż powodowała ona produkcję dużej ilości niebezpiecznej dla zdrowia czarnej żółci. Zgodnie z tradycją, którą znamy, soczewica ${ }^{103}$ została również przez niego oceniona jako pożywienie trudne do strawienia w żołąd$\mathrm{ku}^{104}$. Dodatkowo lekarz zaznaczył, że $\varphi \alpha \kappa \hat{\eta}^{105}$ przyrządzona z nasion pozbawionych łusek wolno przechodzi przez organizm ${ }^{106}$. Orybazjusz powrócił do całościowej natury $\varphi \alpha \kappa \hat{\eta}^{107}$, gdy w jednym z rozdziałów trzeciej księgi swoje-

\footnotetext{
${ }^{91}$ Por. tamże 149, 6-8.

${ }_{92}$ Por. tamże $149,8$.

${ }^{93}$ Por. tamże $149,9$.

${ }^{94}$ Por. tamże 149, 9-10.
}

${ }^{95}$ Orybazjusz żył w IV w. po Chr., był przybocznym lekarzem cesarza Juliana Apostaty. W latach 361-363 sporządził wyciągi z prac wybitnych medyków. Dzieło to, określane jako Collectiones medicae, składało się najprawdopodobniej z siedemdziesięciu ksiąg, z których do naszych czasów zachowało się jedynie dwadzieścia pięć. Orybazjusz ślepo przejmował wszystkie poglądy swojego poprzednika, Galena. Więcej np. w: B. Baldwin, The Career of Oribasius, „Acta Classica” 18 (1975) 85-97; M. Grant, Introduction, w: Oribasius, Dieting for an Emperor, A translation of Books 1 and 4 of Oribasius' Medical compilations with an Introduction and Commentary, ed. M. Grant, Leiden 1997, 1-4; J. Scarborough, Oreibasios of Pergamon, EANS 595-596; K. Jagusiak - M. Kokoszko, Życie i kariera Orybazjusza w świetle relacji źródłowych, „Przegląd Nauk Historycznych” 10 (2011) 5-21; ciż, Pisma Orybazjusza jako źródło informacji o pożywieniu ludzi w późnym Cesarstwie Rzymskim, VoxP 33 (2013) t. 59, 339-357.

${ }^{96}$ Por. Oribasius, Collectiones medicae III 9, 2, 2 (w niniejszym artykule posłużono się wydaniem: Oribasii Collectionum medicarum reliquiae, ed. I. Raeder, vol. 1-4, Lipsiae - Berolini 1928-1933).

${ }^{97}$ Por. tamże III 9, 2, 4.

${ }^{98}$ Por. tamże III 9, 1, 1 - 2, 5.

${ }^{99}$ Por. tamże III 13, 10, 1.

${ }^{100}$ Por. tamże III 13, 1, 1 - 13, 2.

${ }^{101}$ Por. tamże III 16, 8, 1.

${ }^{102}$ Por. tamże III 16, 1, 1 - 18, 3.

${ }^{103}$ Por. tamże III 18, 11. 3.

${ }^{104}$ Por. tamże III 18, 1, $1-13,1$.

${ }^{105}$ Por. tamże III 26, 2, 1-2.

${ }^{106}$ Por. tamże III 26, 1, $1-4,1$.

${ }^{107}$ Por. tamże III 29, 1, 1. 
go dzieła omawiał pokarmy powodujące przeczyszczenie ${ }^{108}$. Wyjaśniał tam, że poszczególne elementy wchodzące w skład ziaren soczewicy mają odmienne własności. I tak $\chi v \lambda o ́ s ~ j e s t ~ p r z e c z y s z c z a j a ̨ c y$, natomiast pozostała materia ma właściwości zatrzymujące pracę przewodu pokarmowego i wolno przechodzi

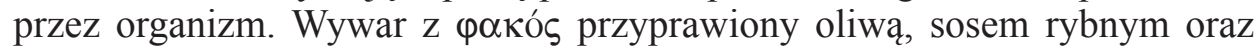
pieprzem ma działanie przeczyszczające, gdyż w czasie gotowania znalazł się w nim sok z soczewicy ${ }^{109}$. Oczywiście ta ostatnia, odgotowana dwukrotnie ${ }^{110}$, trafiła do wykazu pokarmów doprowadzających do zatwardzeń ${ }^{111}$. W końcu

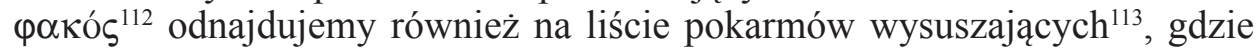
opatrzona została uwagą mówiącą, iż szkodzi na wzrok ${ }^{114}$.

Charakterystyka dietetyczna soczewicy skomponowana przez Aecjusza z Amidy ${ }^{115}$ jest identyczna w swojej treści z ustaleniami poczynionymi przez Dioskuridesa, Galena i Orybazjusza, co wskazuje na trwałość doktryn żywieniowych w VI w., a zatem w czasach działalności tego lekarza ${ }^{116}$. Wziąwszy pod uwagę ten fakt, nie dziwi, że w drugiej księdze Iatricorum Libri pakós

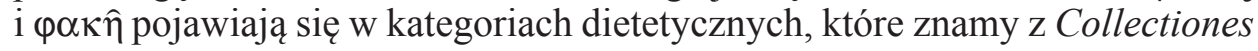
medicae Orybazjusza.

W dorobku autora Epitome ${ }^{117}$ znajdujemy dwie charakterystyki soczewicy, co jest zapewne świadectwem jej znaczenia jako pokarmu i lekarstwa

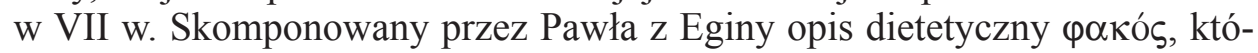
ry notabene nie jest samodzielnym rozdziałem, ale mieści się w większym fragmencie Epitome traktującym o roślinach strączkowych ${ }^{118}$, przedstawia się bardzo tradycyjnie. Soczewica jest, według lekarza, pożywieniem o zakłóco-

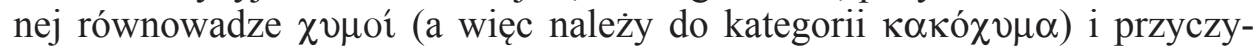

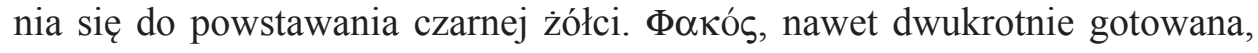

${ }^{108}$ Por. tamże III 29, 1, 1 - 22, 2.

${ }^{109}$ Por. tamże III 29, 1, 1 - 2, 1.

${ }^{110}$ Por. tamże III 30, 6, 1-3.

${ }^{111}$ Por. tamże III 30, 1, 1 - 9, 3.

${ }^{112}$ Por. tamże III $33,1,1$.

${ }^{113}$ Por. tamże III 33, 1, 1 - 6, 3.

${ }^{114}$ Por. tamże III 33, 1, 1-3.

${ }^{115}$ Aecjusz z Amidy (VI w.) studiował w Aleksandrii, być może przez pewien czas praktykował w Egipcie. Znaczną część swojego życia spędził na dworze w Konstantynopolu. Tematyka jego prac (widoczna przewaga dwóch dziedzin - położnictwa i ginekologii) pozwala przypuszczać, że był on osobistym lekarzem cesarzowej Teodory. Jest autorem zbioru pism Iatricorum libri, liczącego szesnaście ksiąg. Por. Kokoszko, Ryby i ich znaczenie, s. 9; J. Scarborough, Aëtios of Amida, EANS 38-39.

${ }^{116}$ Por. Aetius Amidinus, Iatricorum libri I 402, 1-5 (w niniejszym opracowaniu posłużono się wydaniem: Aetii Amideni Libri medicinales I-VIII, ed. A. Olivieri, Lipsiae - Berolini 1935-1950).

${ }^{117}$ Epitome to pisma medyczne zebrane w siedmiu księgach przez Pawła z Eginy, który żył w VII w. Ten wybitny bizantyński lekarz studiował, a następnie leczył i wykładał w Aleksandrii. Pozostawał pod dużym wpływem doktryn swoich poprzedników. Szerzej o Epitome i Pawle z Eginy w: Kokoszko, Ryby i ich znaczenie, s. 15-16; P.E. Pormann, Paulos of Aigina, EANS 629.

${ }^{118}$ Por. Paulus Aegineta, Epitomae medicae I 79, 1, 1-19 (w niniejszym tekście posłużono się wydaniem: Paulus Aegineta, ed. I.L. Heiberg, vol. 1-2, Lipsiae - Berolini 1921-1924). 
silnie oddziałuje na przewód pokarmowy ${ }^{119}$, natomiast wywar z niej $\left(\zeta \xi^{\prime} \mu \alpha\right)$, doprawiony garum i oliwą, wywołuje przeczyszczenie. Kolejną jej cechą jest wiatropędność, którą to redukuje się, gotując owo pożywienie z dodatkiem

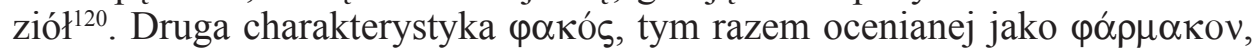
została sporządzona przy okazji umieszczenia tego warzywa na liście substancji prostych w siódmej księdze Epitome ${ }^{121}$. Powtarza ona wszystkie znane dotąd ustalenia farmakologiczno-dietetyczne. Czytamy zatem, iż soczewica wysusza w drugim stopniu, jest natomiast neutralna pod względem czynności rozgrzewania i oziębiania. Jawi się też jako delikatnie ściągająca. Materia jej nasion wysusza tkanki i prowadzi do spowolnienia pracy przewodu pokarmowego. $Z$ kolei wywar $\mathrm{z}$ niej wywołuje przeczyszczenie. $Z$ tego to powodu, chcąc jej użyć jako substancji przeciwdziałającej silnym wypróżnieniom, odlewa się pierwszą wodę w czasie jej gotowania.

Charakterystyka soczewicy, wprowadzona do anonimowego traktatu De cibis $^{122}$ gdzieś w 2. poł. VII w., zawiera te same treści, które dietetyka promowała już w II w. Ze zbiorowego opisu pokarmów uzyskiwanych z roślin zbożowych i strączkowych dowiadujemy się zatem, że $\varphi \alpha \kappa o ́ \varsigma / \varphi \alpha \kappa \hat{~ j e s t ~ z i m n a ~ i ~ s u c h a . ~}$ Wysusza ona ciało i ma w sobie wiele soku melancholicznego. Odpowiada też za osłabienie wzroku i ochładza tkanki ${ }^{123}$. Tradycyjnie przyjmowane dogmaty żywieniowe pojawiają się także na listach pokarmów pogrupowanych wedle ich najistotniejszych cech dietetycznych. W rozdziale na temat substancji, które powodują przeczyszczenie ${ }^{124}$, natrafiamy na dobrze nam znaną ze starszych traktatów dietetycznych wzmiankę o pierwszej wodzie z gotowania soczewicy, przyprawionej oliwą i sosem rybnym garum, jako o środku przyspieszającym wydalanie $^{125}$. Dowiadujemy się także, iż soczewica oraz kapusta, gdy gotowane są po raz drugi, aż do miękkości poprzez wrzucenie ich do gorącej wody, działają jak środek zatwardzający, tak samo zresztą jak i wywar z nich pozostały ${ }^{126}$. Soczewica ${ }^{127}$ została również skategoryzowana jako pokarm o zakłóconej równowadze humoralnej ${ }^{128}$. Autor podał, w kierunku przewagi którego z soków

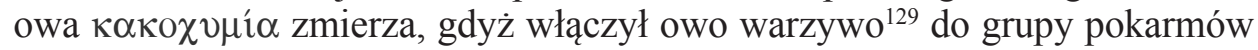

${ }^{119}$ Zapewne chodzi o fakt spowalniania pracy przewodu pokarmowego aż do wywołania zatwardzenia i wolnego przechodzenia strawionych resztek jedzenia przez organizm.

${ }^{120}$ Por. tamże I 79, 1, 1-4.

${ }^{121}$ Por. tamże VII 3, 21, 2-5.

${ }^{122}$ De cibis to traktat napisany najprawdopodobniej przez nadwornego lekarza i dedykowany jednemu z siedmiowiecznych cesarzy bizantyńskich, por. Dalby, Flavours of Byzantium, s. 48.

${ }^{123}$ Por. De cibis II 14-16 (w niniejszym opracowaniu wykorzystano wydanie: De cibis, w: Physici et medici graeci minors, vol. 1-2, ed. I.L. Ideler, Berolini 1841-1842).

${ }^{124}$ Por. tamże XII 1-37.

${ }^{125}$ Por. tamże XII 2-3.

${ }^{126}$ Por. tamże XIII 11-13.

${ }^{127}$ Por. tamże XIV 20.

${ }^{128}$ Por. tamże XIV 1-40.

${ }^{129}$ Por. tamże XVI 6-7. 
melancholicznych $^{130}$. De cibis notuje również, iż soczewica ${ }^{131}$ odpowiada za powstawanie gęstych i lepkich soków ${ }^{132}$, ale pokarm ten ${ }^{133}$, notabene zgodnie $\mathrm{z}$ tradycją dietetyczną, uznany zostaje w tym dziele za pożywny ${ }^{134}$.

4. Zastosowanie soczewicy w procedurach medycznych. Tak popularne pożywienie, jakim była soczewica, która dodatkowo silnie oddziaływała na ludzki organizm, nie mogło pozostać niezauważone przez medycynę. Nie

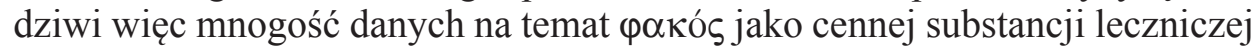
stosowanej w wielu procedurach medycznych, nie tylko zresztą $\mathrm{w}$ dietach.

W I w. po Chr. Dioskurides wymieniał okłady z soczewicy jako główną formę środka leczniczego uzyskiwanego z tej rośliny. Informacja o medycznych zastosowaniach $\varphi \alpha \kappa o ́ \varsigma \mathrm{w}$ postaci kataplazmów zaczyna się w mniej więcej połowie rozdziału, jaki w De materia medica poświęcony został interesującej nas jarzynie strączkowej ${ }^{135}$. Dioskurides podawał, że soczewica ugotowana z ö̉ $\lambda \iota \imath \alpha$ i użyta jako okład łagodzi dolegliwości związanie z podagrą ${ }^{136}$, zaś zmieszana z miodem doprowadza do zasklepienia fistuł, ułatwia usunięcie czy też odpadnięcie strupów oraz oczyszcza owrzodzenia ${ }^{137}$. Z kolei jeśli gotowana jest z octem, przyczynia się do zniknięcia stwardnień i leczy skrofuliczne zapalenia przyusznic ${ }^{138}$, gdy z nostrzykiem (Melilotus officinalis, L) lub pigwą kładzie kres stanom zapalnym oczu ${ }^{139}$, natomiast $\mathrm{z}$ olejkiem różanym kuruje problemy odbytu ${ }^{140}$. Skoro dolegliwości tego ostatniego są poważne, a fistuły znacznych rozmiarów, soczewicę gotuje się razem ze skórką granatu i suchymi różami, dodawszy też miodu ${ }^{141}$. Na złośliwe zmiany i gangrenę działa ten sam specyfik albo też jego odmiana powstająca w wyniku dodania słonej wody $^{142}$. Nadto, na podobne do bąbli narośle, opryszczkę, różę, zmiany typu $\chi i ́ \mu \varepsilon \tau \lambda \alpha$, na zapalenia kanalików mlecznych w czasie laktacji i obrzmienia pomaga okład z soczewicy gotowanej w słonej wodzie ${ }^{143}$.

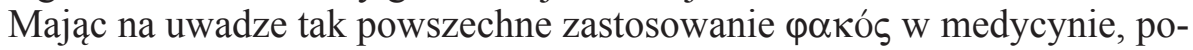
świadczone w dziełach Dioskuridesa, nie dziwi nas fakt, że soczewica była traktowana jako $\varphi \alpha ́ p \mu \alpha \kappa o v$ również przez Galena, a jej charakterystyka zna-

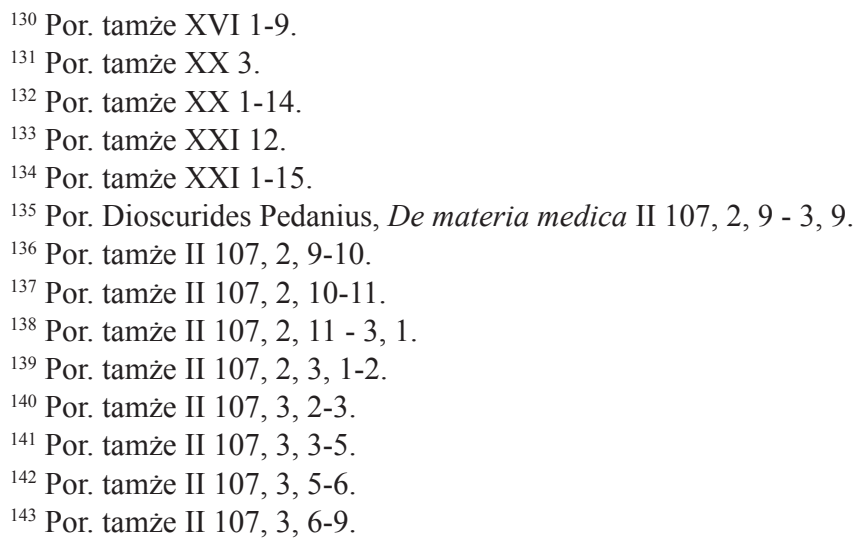


lazła się w De simplicium medicamentorum temperamentis ac facultatibus ${ }^{144}$. W Galenowej terapeutyce wykorzystywano zarówno miąższ tej rośliny, jak

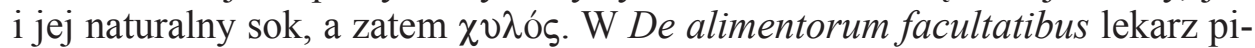
sał, że sok obecny w soczewicy, ze względu na to, iż obdarzony jest właściwo-

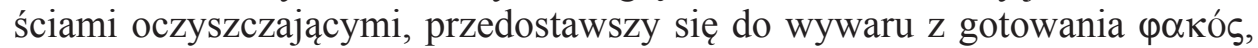
doprawiony do smaku i dla wzmocnienia działania garum oraz oliwą, służył za środek przeczyszczający ${ }^{145}$. Z kolei w jednym z rozdziałów De simplicium medicamentorum temperamentis ac facultatibus, który poświęcony jest leczniczemu działaniu nerek jaszczurek zwanych $\sigma \kappa i \gamma \kappa o s$, notabene stymulującemu pracę jąder ${ }^{146}$, znajdujemy wzmiankę o tym, iż wywar z soczewicy, pity $\mathrm{z}$ dodatkiem miodu ${ }^{147}$, kładzie kres pobudzeniu płciowemu ${ }^{148}$. Zupa $\varphi \propto \kappa \hat{\eta}^{149}$ przyrządzana z tej rośliny ma, jak wiemy, wpływ przeciwny do jej $\chi 0 \lambda o ́ s$, ponieważ wysusza nadmiar soków znajdujących się w żołądku i działa tonizująco nie tylko na niego, ale i na cały przewód pokarmowy ${ }^{150}$. Właśnie z tego

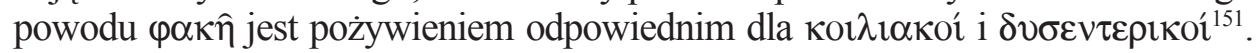

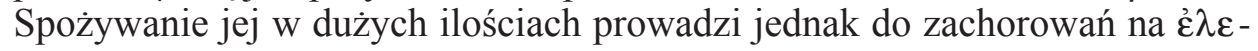

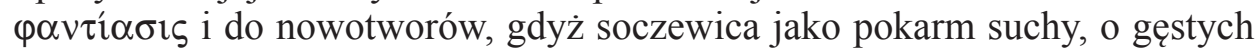
sokach, doprowadza do powstania soków melancholicznych ${ }^{152}$.

$\mathrm{Z}$ rozważań autora De alimentorum facultatibus można również dowiedzieć się, iż soczewica jest dobra dla tych, którzy z natury mają wilgotną strukturę ciała. Wobec tego, co oczywiste, szkodzi tym, którzy są wysusze$\mathrm{ni}^{153}$. Jedzenie jej doprowadza do osłabienia wzroku, ale dzieje się tak tylko w przypadku narządów widzenia osób, które charakteryzują się zwyczajną

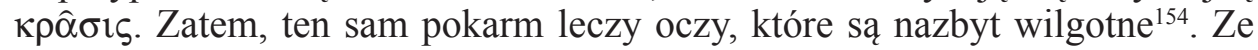
względu na te właściwości, soczewica nie jest też właściwa dla kobiet miesiączkujących, gdyż powoduje powstawanie krwi gęstej i niesprzyjającej wydalaniu moczu ${ }^{155}$. Pomaga jednak kobietom cierpiącym na upławy ${ }^{156}$. Galen

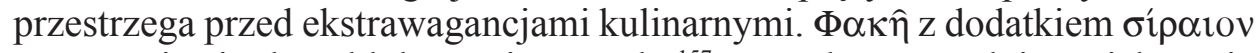
przyczynia się do zablokowania wątroby ${ }^{157}$. Ponadto, powoduje zwiększenie intensywności stanów zapalnych i to nie tylko w wyżej wymienionym orga-

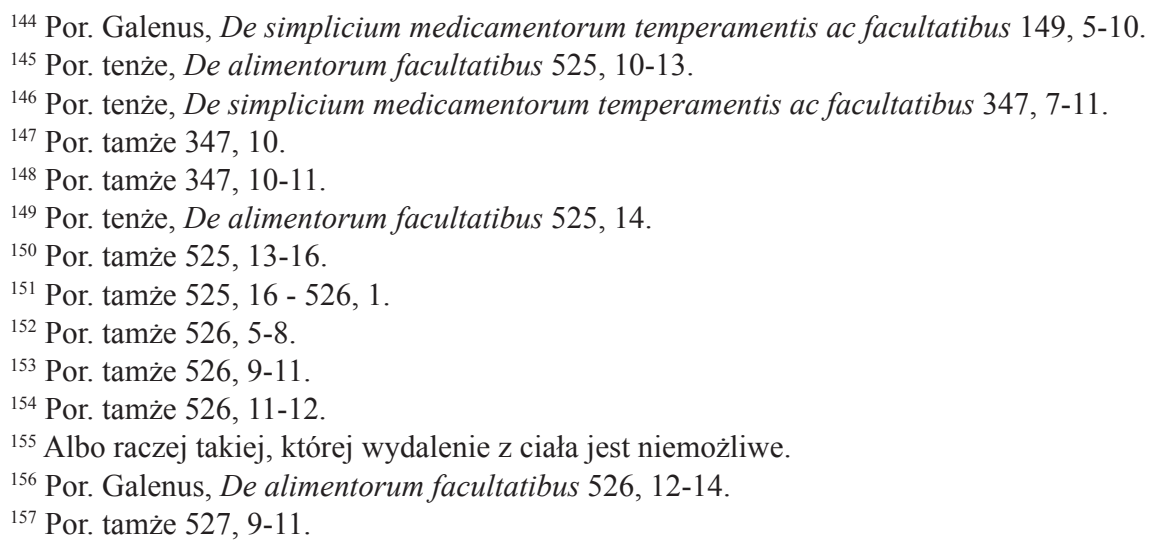


nie, ale i w śledzionie. Temu negatywnemu działaniu naszej potrawy można jednak zapobiec, dodając do niej miodu. Kolejnym ujemnym skutkiem jej spożycia jest zaostrzenie stanów, które objawiają się twardością (opuchnięciem) narządów wewnętrznych ${ }^{158}$. W końcu warto zauważyć, iż omawiane warzywo uznane zostaje za nadające się nie tylko do użytku wewnętrznego. Okład z soczewicy gotowanej $\mathrm{z}$ miodem ${ }^{159}$ zalecany jest $\mathrm{w}$ leczeniu różnego rodzaju powierzchniowych zmian skórnych, które Galen kwalifikował jako złośliwe ${ }^{160}$.

Także w literaturze medycznej IV w. pokós jawi się przede wszystkim jako pokarm leczniczy. Mamy prawo tak twierdzić, ponieważ Orybazjusz wyraźnie wskazywał na zdrowotne skutki jego jedzenia. Są one niemal takie same, jak te, które wymieniał medyk z Pergamonu. Wszelkie różnice istniejące między doktrynami zachowanymi bezpośrednio w dorobku Galena i tymi, które znajdujemy w pismach Orybazujsza, są na tyle niewielkie, że wydają się być raczej rezultatem przyjętej metody skracania tekstu pierwszego z wymienionych medyków, niż wynikiem niewiedzy czy też celowej modyfikacji jego ustaleń. Przyjrzyjmy się zatem najważniejszym konsekwencjom zdrowotnym wynikającym ze spożycia soczewicy, które Orybazjusz zapożyczył z pism Galena. Autor Collectiones medicae podkreślał przede wszystkim wysuszające działanie interesującego nas pokarmu, ale tam, gdzie robił referencje do swojego poprzednika, nie precyzował przy jakich dolegliwościach rzeczone jedzenie działa efektywnie. Dodać wypada, że pominął również wyliczone przez Galena typowe choroby trapiące pacjentów w wyniku obecności me-

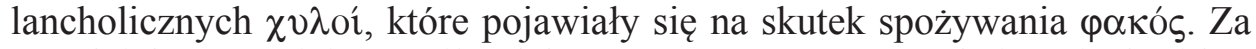
to, tak jak wcześniej uczynił to lekarz z Pergamonu, a przed nim Dioskurides, Orybazujusz wskazał wyraźnie efekty przesuszenia wywoływanego spożywa-

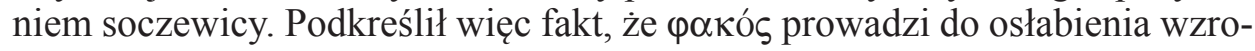
ku. Gdy jednak problemy z ostrością widzenia spowodowane są nadmiarem wilgoci w oczach, ciągnął zgodnie z informacjami wziętym od Galena, potrawa ta leczy ${ }^{161}$. Medyk cesarza Juliana zachował w swoich pismach także dane dotyczące przeczyszczających właściwości wywaru z soczewicy, do którego przeszedł sok z jej ziaren. Dowiadujemy się zatem, że wywar z pakós, zaprawiony garum i oliwą, silnie pobudza pracę układu pokarmowego ${ }^{162}$.

Ustalenia Galena są w dorobku Orybazjusza uzupełniane twierdzeniami pochodzącymi od Dieuchesa ${ }^{163}$. Zaznaczyć należy, że między doktrynami sformułowanymi przez obydwu informatorów lekarza cesarza Juliana nie ma

${ }^{158}$ Por. tamże 527, 11-14.

${ }^{159}$ Por. tenże, De compositione medicamentorum per genera libri VII 734, 3-4 (posłużono się wydaniem: Claudii Galeni Opera omnia, ed. D.C.G. Kühn, vol. 13, Lipsiae 1827).

${ }^{160}$ Por. tamże 733, 9 - 734, 4.

${ }^{161}$ Por. Oribasius, Collectiones medicae I 17, 4, 1-2.

${ }^{162}$ Por. tamże I 17, 1, 3 - 2, 1.

${ }^{163}$ Dieuches - grecki lekarz żyjący na początku III w. prz. Chr. Żadne z napisanych przez niego dzieł nie zachowało się do naszych czasów, stąd jego poglądy znamy tylko z cytatów przekazanych przez innych medyków, np. Galena i Orybazjusza. Por. D. Manetti, Dieukhes, EANS 245-246. 
żadnej sprzeczności. Z fragmentów prac Dieuchesa wynika, że staci zupy zalecana była osobom poważnie chorym i z tego powodu niezdolnym do spożywania pokarmów stałych. Wymieniając $\varphi \alpha \kappa \hat{\eta}$, Dieuches wskazał, że soczewica jest efektywna przede wszystkim w przypadku problemów gastrycznych, których skutkiem jest gwałtowne wydalanie. Na przykład lekarz ten przypisał silne właściwości wysuszające $\tau \varepsilon v \tau \lambda \circ \varphi \alpha \kappa \hat{\eta}^{164}$, czyli zupie z soczewicy gotowanej z burakami, co zresztą winno być uznawane za działanie typowe dla wszystkich odmian $\varphi \alpha \kappa \hat{\eta}$, bowiem wynikało z cech samej soczewicy, a nie $z$ tych, jakie posiadały dodatki do niej używane. Zapewne sam Dieuches podzielał to zdanie, ponieważ takie same następstwa zaadministrowania przypisywał $\varphi \propto \kappa \hat{~ z ~ d z i k i m ~ o g o ́ r k i e m ~ o r a z ~ d y n i a ̨ ~}{ }^{165}$. On również rekomendował ő $\mu \nu \lambda$ ov do $\varphi \alpha \kappa \hat{\eta}$ dla pacjentów, którzy cierpieli na rozwolnienie w czasie gorączki ${ }^{166}$.

Naszkicowany obraz wypada uzupełnić o prezentację typowych sposobów użycia soczewicy, poza już omówionymi zastosowaniami jej do celów dietetycznych. Roślina ta, a właściwie $\alpha \varphi \varepsilon ́ \psi \eta \mu \alpha$ z niej, była używana przy zapaleniach gardła, migdałków i języczka. Orybazjusz wspomniał o tym w dziele zatytułowanym Eclogae medicamentorum, w niewielkim rozdziale, który w zasadzie poświęcony został lekarstwu sporządzanemu z owoców morwy, łagodzącemu dolegliwości migdałków ${ }^{167}$. Lekarz informuje również, że wywaru z soczewicy ${ }^{168}$ używano do płukania gardła. Przy zaostrzeniu zapalenia, dodawano do niego miodu. Natomiast, gdy ropienie na migdałkach pękały, dla ułatwienia wyprowadzenia ropy z organizmu, płukano gardło $\mu \varepsilon \lambda$ íк $\rho \alpha \tau$, $\mathrm{z}$ wywarem $\mathrm{z}$ soczewicy ${ }^{169}$ lub ró $\dot{z}^{170}$. Ten sam wywar ${ }^{171}$, obok innych środ-

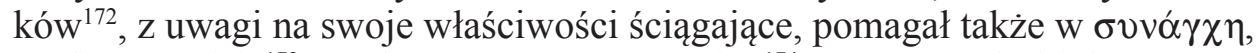
czyli $w$ anginie ${ }^{173}$. Nadto, wywar $z$ soczewicy ${ }^{174}$ stosowany był jako enema,

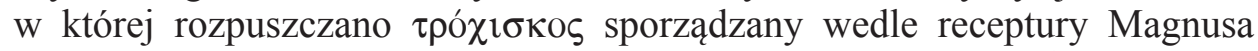
$\mathrm{z}$ Efezu ${ }^{175}$ - tego medykamentu używano w leczeniu dyzenterii ${ }^{176}$. Owa meto-

${ }^{164}$ Por. Oribasius, Collectiones medicae IV 7, 23, 1-2.

${ }^{165}$ Por. tamże IV 7, 23, 1 - 24, 1.

${ }^{166}$ Por. tamże IV 7, 24, 1-3.

${ }^{167}$ Por. tenże, Eclogae medicamentorum XIX 1, 1-3, 6 (w niniejszym artykule wykorzystano wydanie: Oribasii Collectionum medicarum reliquiae, ed. I. Raeder, IV, Lipsiae - Berolini 1933).

${ }^{168}$ Por. tamże XIX 2, 4.

${ }^{169}$ Por. tamże XIX 2, 7.

${ }^{170}$ Por. tamże XIX 2, 1-8.

${ }^{171}$ Por. tamże XXXV 1, 4.

${ }^{172}$ Por. tamże XXXV 1, 2-5.

${ }^{173}$ Por. tamże XXXV 1, 1 - 4, 6.

${ }^{174}$ Por. tamże LIV 6, 5.

${ }^{175}$ Por. tamże LIV 6, 1 - 7, 1. Magnus z Efezu - grecki lekarz żyjący w I w. po Chr. W swoich pracach skupiał się nad poznaniem funkcji serca i układu krążenia, prowadził badania nad tętnem krwi, por. A. Touwaide, Magnus of Ephesos, EANS 519-520.

${ }^{176}$ Por. Oribasius, Eclogae medicamentorum LIV 1, 1 - 22, 6. 
da wprowadzania leczniczych enem w wywarze z omawianej rośliny musiała być dość popularna w medycynie, gdyż Eclogae medicamentorum wymienia ją wielokrotnie.

W VI w. Aecjusz z Amidy często odnosił się do soczewicy jako do elementu diety, lekarstwa lub składnika tegoż. Jej zdolności wysuszające w sposób oczywisty kwalifikowały ją jako pokarm nadający się do leczenia problemów gastrycznych i innych, uznawanych za skutek nadmiaru soków organicznych występujących w danej partii ciała. I tak, w rozdziale dotyczącym postępowania po zbyt obfitych miesiączkach, który notabene, jak sugeruje to Aecjusz, napisany został na podstawie danych pochodzących od Orybazjusza ${ }^{177}$, mowa jest o diecie odpowiedniej w takich przypadkach ${ }^{178}$. Wśród wielu rad znajdujemy i taką, która zaleca serwowanie osłabionym pacjentkom zupy opartej na mące z soczewicy ${ }^{179}$, gotowanej z octem, burakami, sumakiem garbarskim lub

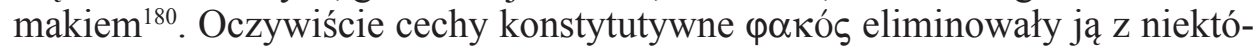
rych diet. Na przykład, omawiając sposób odżywania odpowiedni dla osób starszych ${ }^{181}$, medyk sugerował wykluczenie z niego pokarmów, które rodzą gęste soki, a więc, jak wymieniał, bulw szafirków, grzybów, soczewicy - dokładniej zupy z tejże $e^{182}$ - ostryg i temu podobnych ${ }^{183}$.

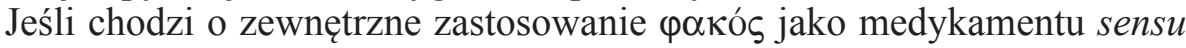
stricto, to na przykład, pisząc o karmieniu piersią ${ }^{184}$, a doszedłszy do problemu nadmiernej laktacji ${ }^{185}$, Aecjusz z Amidy zalecał posypanie ${ }^{186}$ piersi gotowaną soczewicą ${ }^{187}$. Zapewne jej zdolność do wysuszania miała położyć kres przepływowi mleka w kanalikach tam się znajdujących.

Soczewica i otrzymywane z niej produkty najczęściej wchodziły w skład mniej lub bardziej złożonych lekarstw. Aecjusz z Amidy zachował formułę, wcześniej cytowaną przez Galena ${ }^{188}$, która uwzględniała płyn powstały w wy-

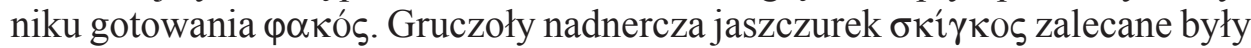
w niej jako środek pobudzający pracę jąder. Odwrotne działanie miał natomiast dawać wywar z soczewicy z dodatkiem miodu, który, jak utrzymywał

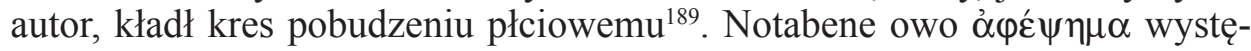
puje w recepturach wielokrotnie. Oto jeszcze jedno exemplum. W kuracji wy-

\footnotetext{
${ }^{177}$ Właściwy odpowiednik w wydanych oficjalnie tekstach Orybazjusza nie został zidentyfikowany.

${ }^{178}$ Por. Aetius Amidinus, Iatricorum libri III 119, 1-13.

${ }^{179}$ Por. tamże III 119, 5-6.

${ }^{180}$ Por. tamże III 119, 5-7.

${ }^{181}$ Por. tamże IV 30, 1-89.

182 Por. tamże IV 30, 49.

${ }^{183}$ Por. tamże IV 30, 47-51.

${ }^{184}$ Por. tamże IV 6, 1-54.

${ }^{185}$ Por. tamże IV 6, 49-54.

${ }^{186}$ Być może autorowi chodziło o jakąś formę okładu. Lekarz użył czasownika $\kappa \alpha \tau \alpha \pi \alpha ́ \sigma \sigma \omega$.

${ }^{187}$ Por. Aetius Amidinus, Iatricorum libri IV 6, 51.

${ }^{188}$ Por. tamże I 119, 1-4.

${ }^{189}$ Por. tamże I 119, 3-4.
} 
kwitów ( $\dot{\xi} \xi \alpha v \theta \eta \dot{\eta} \mu \alpha \tau \alpha)$ i innych dolegliwości na powierzchni skóry powstałych w wyniku złego żywienia małych dzieci ${ }^{190}$, medyk polecał przemywanie chorych miejsc wywarem z róż albo z soczewicy ${ }^{191}$, ale odradzał stosowanie

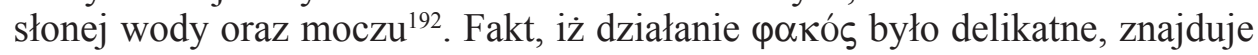
z kolei odbicie w jej wykorzystaniu w lekach oftalmologicznych. Przy opuchliznach oczu ${ }^{193}$, mianowicie, Aecjusz z Amidy radził ugotowanie soczewicy ${ }^{194}$, przeciśnięcie jej przez drobne sitko lub materiał, dodanie do masy miodu i posmarowanie tak uzyskanym lekarstwem chorego organu ${ }^{195}$.

Dzieło życia Pawła z Eginy udowadnia, że w teorii, a zapewne także w praktyce medycznej przełomu VI i VII w., soczewica pozostawała istotnym środkiem o znaczeniu terapeutycznym. Nadal więc używano jej w leczniczych

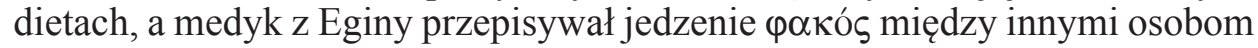
cierpiącym na zakłócenia trawienne spowodowane nadużyciem alkoholu ${ }^{196}$. Tłumaczył, że jeśli pacjent cierpiał na ból głowy z powodu nadmiaru soków w żołądku - występujący, jak można się domyślić, w skutek nadużycia wina - należało nakarmić go soczewicą. Oczywiście pokós wysuszała nadmiar $\chi \cup \mu$ ó $^{197}$. Soczewica wciąż też była administrowana w formie kataplazmów. Wiemy to choćby z Pawłowego fragmentu dotyczącego odleżyn. Lekarz mianowicie zaświadczył, że w momencie, gdy zapalenie kości krzyżowej ${ }^{198}$, które zdarza się w wyniku długotrwałego leżenia spowodowanego chroniczną chorobą, przechodziło do fazy ropiejących ran, przykładano na chore miejsce soczewicę ${ }^{199}$ gotowaną ze skórkami granatów ${ }^{200}$. Nadto, przy jątrzących się stanach zapalnych oczu lub powiek (zwanych ö $v \theta \rho \alpha \kappa \varepsilon \varsigma)^{201}$, które klasyfikowano jako złośliwe, Paweł z Eginy zalecał okład z soczewicy ${ }^{202} \mathrm{z}$ miodem lub gotowanymi pigwami ${ }^{203}$. Podobnych danych jest $\mathrm{w}$ dorobku tego medyka znacznie więcej. W praktyce medycznej nadal stosowano również wywar z soczewicy. Paweł doradzał na przykład, by przy problemach z łupieżem ${ }^{204}$, po dokładnym ostrzyżeniu głowy, przemywać jej skórę gorącą wodą, w której odgotowane

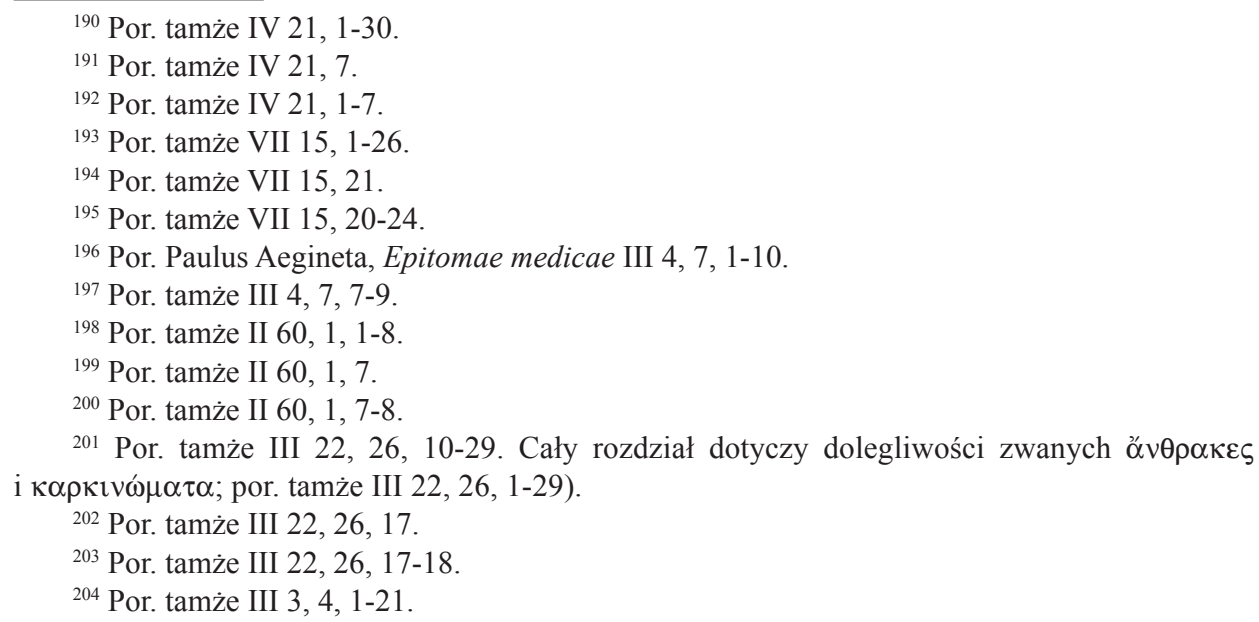


zostały nasiona interesującej nas rośliny. Gdy z miejsc zajętych chorobą pojawiały się wysięki, stosowano też samą $\varphi \propto \kappa o ́ \varsigma^{205}$ jako kataplazm. Następnym przykładem może być traktowanie $\alpha \dot{\varphi} \varepsilon ́ \psi \eta \mu \alpha$ jako sui generis medykamentu oftalmologicznego. Z chwilą, gdy na powiekach powstawały wrzodziejące

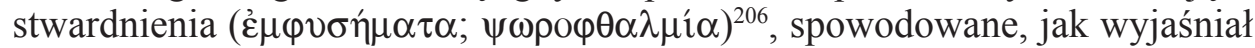
autor, napływem w te miejsca soków o słonym i alkalicznym charakterze ${ }^{207}$, lekarstwem okazywał się również wywar z soczewicy ${ }^{208}$, którym zapewne przemywano chore części ciała. I tym razem przytoczone przykłady stanowią jedynie ułamek wiedzy farmakologicznej w analizowanej przez nas kwestii medycznego zastosowania pokós.

5. Zastosowanie soczewicy w sztuce kulinarnej. Zaprezentowany dotąd materiał udowadnia stałą obecność soczewicy jako tematu rozważań lekarzy antyku i wczesnego Bizancjum. Jeżeli tak, to z pewnością rzuca też światło na jej znaczną rolę jako pokarmu, którym żywiono się w interesującym nas okresie.

Przyjrzyjmy się wobec tego również kulinarnym zastosowaniom rośliny, która stanowi przedmiot naszych badań. Źródła medyczne mówią sporo na temat sposobów przyrządzania soczewicy jako wartościowego pożywienia, a także podają wiele wskazówek pozwalających uniknąć niebezpieczeństw wynikających z jej właściwości. Najszczegółowiej problemy te omówił Galen i Orybazjusz, choć już w dziełach Dioskuridesa odnajdziemy podstawowe informacje dotyczące gotowania jej nasion. Wskazówki te powtarzają się w całej literaturze medycznej sięgającej VII w. Z De materia medica można wnioskować, że $\varphi \propto \kappa o ́ \varsigma / \varphi \alpha \kappa \hat{n}$ była jadana często. U niektórych, co sugerował Dioskurides, częstotliwość jej spożycia była wręcz zbyt duża, tak że mówiono, iż doprowadza ona do osłabienia wzroku ${ }^{209}$, co notabene traktaty medyczne uzasadniały fizjologicznie, poszukując etiologii tej zapewne dość powszech-

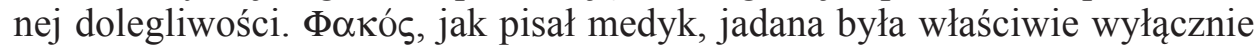
$\mathrm{w}$ postaci gotowanej. Poddawano ją temu procesowi wraz z łuską ${ }^{210}$, czekając do momentu, kiedy skończy wydawać z siebie ciemny sok ${ }^{211}$. Istniał jednak lepszy sposób jej przyrządzania - należało odgotować ją kilka razy po uprzednim obraniu z łusek i odlaniu pierwszej wody, w której poddana była działaniu temperatury ${ }^{212}$. Co więcej, lekarz informował czytelników swojego dzieła, że wywar powstały w wyniku odgotowania soczewicy używany był do

\footnotetext{
${ }^{205}$ Można domniemywać, że spożytkowywano w tym celu gotowaną soczewicę.

${ }^{206}$ Por. tamże III 22, 8, 1-11.

${ }^{207}$ Por. tamże III 22, 8, 1-4.

${ }^{208}$ Por. tamże III 22, 8, 4-5.

${ }^{209}$ Por. Dioscurides Pedanius, De materia medica II 107, 1, 1.

${ }^{210}$ Por. tamże II 107, 1, 2-3.

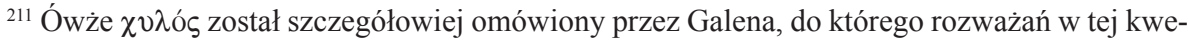
stii należy odesłać Czytelnika.

${ }^{212}$ Por. Dioscurides Pedanius, De materia medica II 107, 1, 6.
} 
celów medycznych, gdyż uważano go za skuteczny środek doprowadzający do przeczyszczenia ${ }^{213}$.

Dioskurides zachował całą listę substancji stanowiących dodatki do przy-

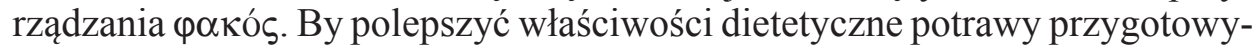
wanej z tego produktu w zakresie jej oddziaływania na reumatyzm brzuszny,

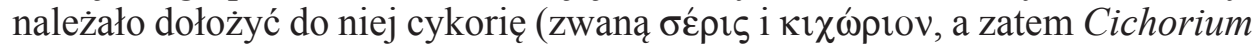
intybus, L), babkę (Plantago maior, L), andrachnę (Andrachne telephioides, L), czerwone buraki, jagody mirtowe, skórkę granatu, suszone winogrona, nieszpułki, pigwy, gruszki, daktyle tebańskie, gotowane galasówki albo owoce sumaka garbarskiego (Rhus coriaria, L) ${ }^{214}$. Ponadto, trzeba było gotować soczewicę $\mathrm{z}$ dodatkiem octu ${ }^{215}$. Omawiane źródło nie informuje o właściwych proporcjach poszczególnych składników potraw przyrządzanych na bazie naszego warzywa, ale można założyć, że albo nie były one istotne, albo też były powszechnie znane w świecie medyczno-kulinarnym. Dioskurides podał również, że z $\varphi \alpha \kappa o ́ \varsigma$ gotuje się zupę zwaną $\varphi \alpha \kappa \hat{\eta}^{216}$. Dodaje się do niej na przykład buraki ${ }^{217}$, a potrawa ta doprowadza do zatrzymania pracy przewodu pokarmowego ${ }^{218}$.

Galen, jako autor De alimentorum facultatibus, poświecił soczewicy relatywnie dużo miejsca ${ }^{219}$. Fakt ten uznać można za odzwierciedlenie jej istotnej roli jako pokarmu w diecie ludzi II w. Konkludować też wypada, iż pokós miała największe znaczenie wśród roślin strączkowych, gdyż to właśnie od dyskusji na jej temat medyk z Pergamonu rozpoczął swoje wynurzenia

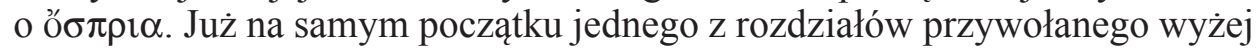
dzieła pada stwierdzenie mówiące, że soczewica nie nadaje się do produkcji chleba ${ }^{220}$. Tą konkluzją autor niejako kończył swoje poprzednie rozważania dotyczące zbóż, które to poddane zostały analizie przede wszystkim jako mniej lub bardziej przydatny produkt do wyrobu pieczywa. Lekarz uznał, że

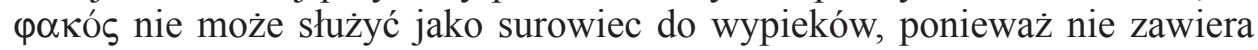
w sobie elementu, który sam nazwał „thustym"221. Oznaczało to tym samym, że soczewica stanowiła podstawę do przyrządzania potraw nie pieczonych, lecz gotowanych.

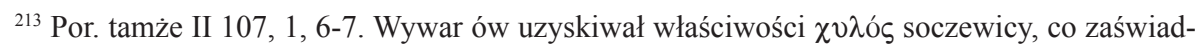
czają cytowane powyżej ustalenia Galena.

${ }^{214}$ Por. tamże II 107, 2, 1-6.

${ }^{215}$ Por. tamże II 107, 2, 6-8.

${ }^{216}$ Por. tamże II 123, 2.

${ }^{217}$ Ta odmiana zwana była $\tau \varepsilon v \tau \lambda$

Dioskuridesa. Medyk nie wymieniał także słynnej $\varphi \alpha \kappa o \pi \tau \iota \sigma \alpha ́ v \eta$.

${ }^{218}$ Por. Dioscurides Pedanius, De materia medica II 123, 1-2.

${ }^{219}$ Por. Galenus, De alimentorum facultatibus 525, 6 - 525, 16.

${ }^{220}$ Por. tamże 525, 7.

${ }^{221} \mathrm{~W}$ odniesieniu do zbóż określał ten element jako $\gamma \lambda \hat{i} \sigma \chi \rho o v$. 
Soczewicę jadano zarówno z łuską, jak i bez niej. Wiadomość ta pochodzi od Galena, który rozważał właściwości dietetyczne tej osłonki ziarna ${ }^{222}$. Do-

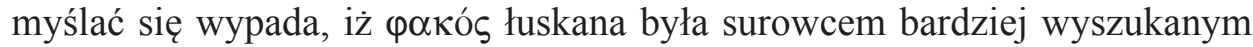
i droższym niż niełuskana. Często starano się pozbawić soczewicę jej naturalnego soku, a zatem $\chi v \lambda o ́ s$, któremu, jak pamiętamy, przypisywano określone wartości dietetyczne, to jest właściwości przeczyszczające. By ograniczyć natężenie tego działania, o czym informował nas lekarz w De simplicium medicamentorum temperamentis ac facultatibus, odlewano pierwszą wodę $\mathrm{z}$ jej gotowania ${ }^{223}$. Z De alimentorum facultatibus wiemy też, iż w czasie kontaktu z płynem ów $\chi 0 \lambda$ ós przechodził do niego, a zatem do wody, w której nasiona soczewicy były poddawane obróbce. Wywaru używano, o czym również pisał medyk, jako sui generis lekarstwa, doprawiając go garum i oliwą ${ }^{224}$.

Z soczewicy gotowano potrawę zwaną $\varphi \propto \kappa \hat{\eta}^{225}$, która silnie wpływała na przewód pokarmowy ${ }^{226}$. By kontrolować jej działanie, łączono

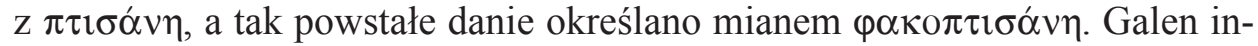
formował, iż do przyrządzania tej zupy używa się mniej jęczmienia a więcej soczewicy, gdyż z tych dwóch produktów to ten pierwszy znacznie bardziej pęcznieje w trakcie gotowania ${ }^{227}$. $\mathrm{Z}$ rozdziału stanowiącego część $D e$ alimentorum facultatibus dowiadujemy się sporo o przyrządzaniu $\varphi \alpha \kappa \hat{\eta}$

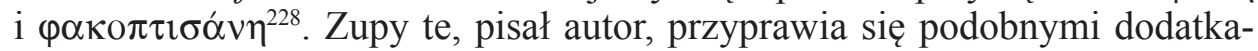
mi jak te używane do $\pi \tau \imath \sigma \alpha ́ v \eta^{229}$. Ponadto, dokłada się do nich także cząbru i mięty polej, które to czynią potrawę jeszcze smaczniejszą i łatwiejszą do

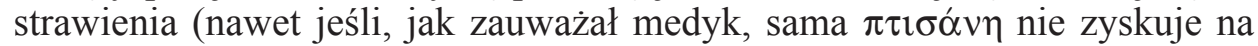
ich dodaniu, a najlepsza jest $\mathrm{z}$ dodatkiem jedynie kopru, pora, soli i oliwy).

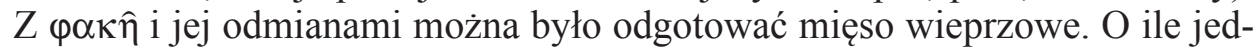
nak z $\pi \tau \imath \sigma \alpha ́ v \eta \eta$ gotowano mięso świeże, z $\varphi \alpha \kappa \hat{n}$ najlepiej było przygotowywać solone. Z

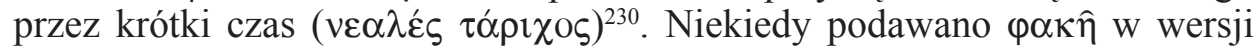
luksusowej, to znaczy na słodko. Wówczas dodawano do niej ${ }^{231}$ zredukowanego moszczu winnego, zwykle nazywanego oípoıv. Galen przekazał nam cenną uwagę o praktykach kulinarnych jego czasów, zaznaczając, że w ten sposób kucharze przygotowywali tę potrawę dla ludzi bogatych. Opisywana

${ }^{222}$ Por. Galenus, De alimentorum facultatibus 525, 8-10.

${ }^{223}$ Por. tenże, De simplicium medicamentorum temperamentis ac facultatibus 149, 9-10. Oczywiście czynność tę można było powtarzać, a typowe procedury kulinarne i medyczne przewidywały trzykrotne gotowanie tego typu produktów żywnościowych.

${ }^{224}$ Por. tenże, De alimentorum facultatibus 525, 10-13.

${ }^{225}$ Por. tamże 525, 14.

${ }^{226}$ Por. tamże 525, 13-16.

${ }^{227}$ Por. tamże 526, 15 - 527, 3.

${ }^{228}$ Por. tamże 527, 4 - 528, 2.

${ }^{229}$ Są to zatem: koper, por, odrobina soli oraz oliwy.

${ }^{230}$ Por. Galenus, De alimentorum facultatibus 527, 14 - 528, 2.

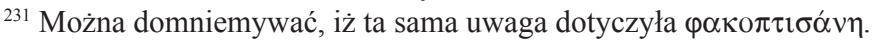


receptura wprawiła jednak medyka w zdziwienie, ponieważ z punktu widzenia dietetyki została niewłaściwie opracowana. Zupa ta bowiem, charakteryzując się gęstymi sokami, wymagała dodatków, które by je rozcieńczały i rozcinały, a nie dodatkowo zagęszczały ${ }^{232}$. Tymczasem $\varphi \alpha \kappa \hat{~ z ~ \sigma i ́ p \alpha ı v ~ c z y n i ~} \chi v \mu$ oí $^{2}$ nazbyt gęstymi i w efekcie doprowadza do zablokowania wątroby ${ }^{233}$. Lekarz z Pergamonu twierdził jednak, że można temu zaradzić, przez co dawał nadzieję zwolennikom słodkiego smaku tego dania. Rozwiązanie tkwiło w dołożeniu do zupy miodu ${ }^{234}$.

Galen scharakteryzował również $\tau \varepsilon v \tau \lambda \circ \varphi \alpha \kappa \hat{\eta}$. Medyk powołał się przy tej okazji na poglądy Herakleidesa $z$ Tarentu ${ }^{235}$. We fragmencie, który mówi o tej potrawie, brak jest szczegółowego przepisu. Nazwa podpowiada jednak, iż do $\varphi \propto \kappa \hat{n}$ dodawano sporo buraków, a słowa Galena świadczą o tym, że doprawiano ją albo solą, albo też słodkim garum ${ }^{236}$. Drugi z wymienionych lekarzy zalecał $\tau \varepsilon v \tau \lambda о \varphi \alpha \kappa \hat{\eta}$ nie tylko osobom zdrowym, ale i chorym. Jest to bowiem, jak wyjaśniał, pokarm jednoczący w sobie dwie przeciwstawne cechy pochodzące $z$ dwóch rodzajów pożywienia. $Z$ jednej strony buraki sprzyjają spowalnianiu trawienia, $z$ drugiej zaś soczewica stosunkowo szybko przechodzi przez przewód pokarmowy ${ }^{237}$. W rezultacie sok powstały w czasie przyswajania obydwu reprezentuje właściwości mieszane ${ }^{238}$.

Orybazjusz wzbogaca naszą wiedzę na temat soczewicy, potraw z niej gotowanych oraz ich właściwości dzięki wypisom z dorobku swoich dwóch najważniejszych informatorów w tej kwestii, to znaczy Galena i Dieuchesa. Informacje zapożyczone od pierwszego $\mathrm{z}$ nich są $\mathrm{w}$ zasadzie powtórzeniem tego, co już wiemy ${ }^{239}$. Wzorem swojego poprzednika, Orybazjusz przemieszał w strukturze wewnętrznej rozdziału traktującego o soczewicy, notabene znacznie skróconego w stosunku do pierwowzoru, dane kulinarne i dietetyczne. $\mathrm{Z}$ jego Collectiones medicae, podobnie jak z De alimentorum facultatibus Galena, wnosić zatem należy, że w IV w. najprostszym sposobem przyrządzania tej rośliny było gotowanie jej ziaren w wodzie, bez odlewania płynu i bez

\footnotetext{
232 Por. Galenus, De alimentorum facultatibus 527, 7-9.

${ }^{233}$ Por. tamże 527, 9-11.

234 Por. tamże 527, 11-14.

${ }^{235}$ Herakleides z Tarentu był lekarzem żyjącym w I w. prz. Chr. W starożytności cieszył się dużą
} renomą. Więcej na jego temat pod hasłem Herakleides of Taras autorstwa F. Stoka (EANS 370-371).

${ }^{236}$ Zapewne chodziło o garum z dodatkiem miodu.

${ }^{237} \mathrm{Z}$ tych wyjaśnień wynika, iż soczewica używana do $\tau \varepsilon v \tau \lambda \circ \varphi \alpha \kappa \hat{\eta}$ nie była wcześniej odgo-

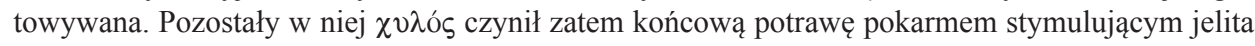
do wydalania.

${ }^{238}$ Por. Galenus, De alimentorum facultatibus 529, 1-6. Warto dodać, iż oprócz opisanej wyżej

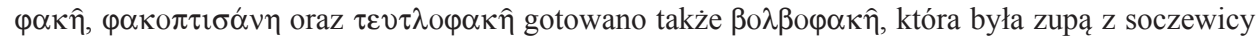
z dodatkiem bulw hiacyntów (to znaczy znanych nam szafirków). Wymieniona została ona m.in. przez Atenajosa z Naukratis [Deipnosophistae IV 158 b (47, 18-19, Kaibel)]. Na temat bulw por.

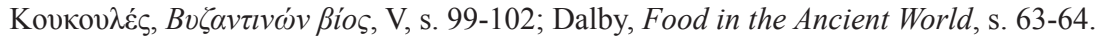

${ }^{239}$ Por. Oribasius, Collectiones medicae I 17, 1, 3 - 4, 2. 
stosowania jakichkolwiek dodatków. Ten proces obróbki termicznej musiał trwać do momentu uzyskania wymaganej miękkości. Tak powstała potrawa, jak możemy konkludować, odznaczała się cechami delikatnie ściągającymi oraz stymulowała wydalanie. Orybazjusz przedstawia również drugi wariant przyrządzania soczewicy, a czyni to o wiele czytelniej niż jego poprzednik. Pisze mianowicie, że jeśli pokós zostanie ugotowana dwukrotnie - to znaczy, jeśli wpierw odgotuje się ją, a potem przełoży do drugiego naczynia, chroniąc ją przy tym przed kontaktem z zimnem otoczenia, i będzie się ją trzymać na ogniu aż nabierze wymaganych $\operatorname{cech}^{240}$ - to uzyskana w ten sposób potrawa, straciwszy zdolność do stymulacji wypróżnienia, ale zatrzymawszy siłę wysuszania, będzie absorbowała nadmiar soków obecnych w żołądku i przywracała jego wewnętrzny balans, tonizując przewód pokarmowy. Opis ten, w sposób dla wszystkich oczywisty, sugeruje, że takie danie miało silne właściwości terapeutyczne służące przeciwdziałaniu nadmiernym wypróżnieniom spowodowanym przez problemy gastryczne. Wywar z soczewicy z kolei, doprawiony garum i oliwą, był używany jako lekarstwo przeczyszczające, gdyż przyjmował cechy $\chi 0 \lambda$ ó znajdującego się w nasionach ${ }^{241}$. Warto także zaznaczyć, iż Orybazjusz, podobnie jak jego poprzednik z Pergamonu, zwracał uwagę na to, czy nasiona pokós były gotowane z łuską, czy też bez niej. Obrana soczewica traci swoje cechy ściągające, gdyż te obecne są w osłonkach ziaren, staje się ponadto bardziej pożywna od niełuskanej. $Z$ drugiej jednak strony, tak przygotowana zawiera jeszcze więcej gęstych $\chi v \mu o i ́$, wolno i z trudem przechodzi przez organizm, a nadto nadal wysusza, ale już nie tak intensywnie jak

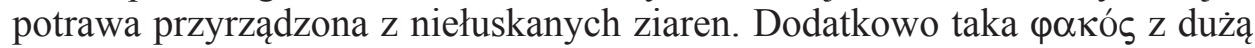
efektywnością zakłóca balans humoralny w kierunku przyczyniania się do powstania w organizmie znacznych ilości czarnej żółci ${ }^{242}$.

Orybazjusz wybrał z dorobku Galena również informacje traktujące o specyficznych potrawach powstałych na bazie soczewicy. Zamieścił je jednak nie we fragmencie mówiącym o samej pokós, ale w rozdziale opartym na doktrynach medyka z Pergamonu dotyczących przyrządzania pokarmów ${ }^{243}$. Lekarz cesarza Juliana włączył tam znane nam już dane o gotowaniu $\varphi \alpha \kappa \hat{\eta}$ z dodatkiem oípoıov - choć właściwie nie opatrzył ich komentarzem na temat dietetycznych niebezpieczeństw, jakie niesie ze sobą jedzenie tak przyrządzonej potrawy ${ }^{244}$ - następnie przepis na $\varphi \propto \kappa o \pi \tau \iota \sigma \alpha ́ v \eta$, zawierający ogólne wskazówki co do proporcji poszczególnych składników i użytych przypraw ${ }^{245}$,

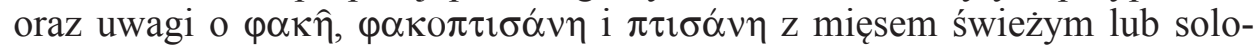

${ }^{240}$ Informacje na temat techniki gotowania $\varphi \alpha \kappa o ́ \varsigma$ podają np. Galen (De alimentorum facultatibus 460, 4 - 462, 14) i Aecjusz z Amidy (Iatricorum libri I 402, 1-5).

${ }^{241}$ Informacje kulinarne - Oribasius, Collectiones medicae I 17, 1, 1 - 4, 1.

${ }^{242}$ Por. tamże I 17, 1, 1 - 3, 4.

${ }^{243}$ Por. tamże IV 1, 1, 1 - 45, 2.

${ }^{244}$ Por. tamże IV 1, 24, 1 - 25, 1.

${ }^{245}$ Por. tamże IV 1, 22, 1 - 24, 1. 
nym $^{246}$. Wzmiankował też $\tau \varepsilon v \tau \lambda \circ \varphi \alpha \kappa \hat{\eta}$, zachowując szczegóły na temat proporcji buraków do soczewicy oraz metod przyprawiania tej zupy na słono lub słono-słodko. Uznał ją zresztą za pokarm zdrowy. W swoich rozważaniach pominął autorytet Herakleidesa z Tarentu, na który powoływał się Galen w De alimentorum facultatibus ${ }^{247}$.

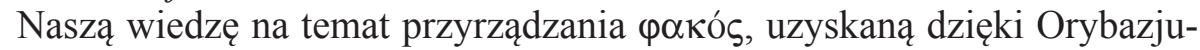
szowi, poszerzają informacje pochodzące od Dieuchesa ${ }^{248}$. Ten drugi pozostawił nam bowiem kilka detali odnoszących się do sposobu przygotowania ziaren soczewicy do procesu poddania jej obróbce czysto kulinarnej, a także dodał parę szczegółów uzupełniających nasze wiadomości, uzyskane dzięki Dioskuridesowi i Galenowi, co do potraw z tej rośliny. Zacznijmy od zupełnie nowych danych. $\mathrm{Z}$ tekstu zachowanego w czwartej księdze Collectiones medica $^{249}$ dowiadujemy się, jak wyglądała technologia łuskania soczewicy. Lekarz pisał, iż nasion nie poddawano prażeniu ${ }^{250}$, ale mieszano z nimi drobny popiół z drewna jodłowego w ilości dwa razy większej niż objętość ziaren przeznaczonych do oczyszczenia. Soczewicę łuskano, delikatnie uderzając w mieszaninę, znajdującą się - czego wypada się domyślać - w moździerzu. Gdy łupiny zostały już oddzielone, przesiewano wszystko przez drobne sito, co powodowało opadnięcie popiołu na spód. Z oczyszczonych nasion przygotowywano właściwą zupę. By ugotować tę potrawę, co również zdradził nam Dieuches, brano jedną kotyle soczewicy na siedem kotylai wody ${ }^{251}$. Przepis Dieuchesa na $\varphi \propto \kappa \hat{\eta}$ przewidywał następujące kroki ${ }^{252}$. Soczewicę gotowano po kilkakrotnym płukaniu. W czasie przyrządzania zwyczajowo dodawano do niej kopru ogrodowego albo mięty polej, ale nie dolewano oliwy. Do zupy dorzucano też soli i wlewano nieco octu. Ta ostatnia ingrediencja winna być użyta, co zauważył autor, dopiero, gdy zupa była już na wpół ugotowana ${ }^{253}$.

Dieuches zaznaczył, iż do przeznaczonej dla pacjenta chorującego na rozwolnienie, któremu nie towarzyszyła gorączka, zamiast octu dolewano kyathos wina, najlepiej o bardzo dobrym aromacie. Niekiedy, w celu zaradzenia problemom gastrycznym, w miejsce wina lub octu dorzucano do soczewicy pokrojone gruszki i pigwy, a więc owoce odznaczające się wysoką kwasowością, i gotowano je wraz z nią. Dieuches poinformował nas także o istnieniu wielu specyficznych odmian omawianej zupy, między innymi $\tau \varepsilon v \tau \lambda o \varphi \propto \kappa \hat{\eta}$, którą znamy z dorobku Galena. Pisał bowiem, że chcąc doprowadzić do wysuszenia przewodu pokarmowego ${ }^{254}$,

\footnotetext{
${ }^{246}$ Por. tamże IV 1, 25, 1 - 26, 1.

${ }^{247}$ Por. tamże IV 1, 26, 1 - 27, 1.

${ }^{248}$ Por. tamże IV 7, 1, 1 - 38, 4.

${ }^{249}$ Por. tamże IV 7, 21, 1-5.

${ }^{250}$ Postępowano tak dla łatwiejszego usunięcia łuski np. $\mathrm{z}$ jęczmieniem.

${ }^{251}$ Por. Oribasius, Collectiones medicae IV 7, 22, 2 - 23, 1.

${ }^{252}$ Por. tamże IV 7, 21, 5 - 22, 2.

${ }^{253}$ Ocet ściągał, a zatem utwardzał strukturę substancji spożywczych.

${ }^{254}$ Por. Oribasius, Collectiones medicae IV 7, 23, 1-2.
} 
należy wziąć młode liście buraczane ${ }^{255}$ i gotować je z soczewicą 256 . Podobnie

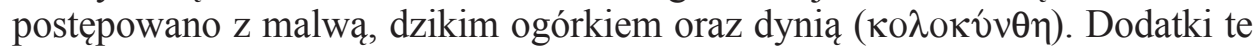
wtedy drobno krojono ${ }^{257}$. W tekście nie ma mowy o innych ingrediencjach modyfikujących smak potrawy, ale można się domyślać, iż były one analogiczne do tych, które wymieniał Galen, pisząc o $\varphi \propto \kappa \hat{\eta} z$ burakami. Lekarz podał również sposób leczenia tych, którzy cierpieli na rozwolnienie w czasie gorączki - do serwowanej im zupy z soczewicy należało dodać $\alpha \mu \nu \lambda o v^{258}$.

W końcu Dieuches informował (a jego słowa przytoczył Orybazjusz

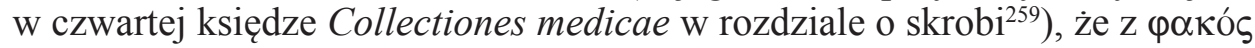
otrzymywano wymienione powyżej ó $\mu v \lambda \mathrm{v}^{260}$. Produkowano je zresztą, jak zapewniał swoich czytelników autor, także z innych roślin strączkowych. Po wysuszeniu dodawano go do potraw przeznaczonych dla osób cierpiących na problemy trawienne, zwłaszcza do zup na bazie prosa, suchego chleba albo do $\pi \tau 1 \sigma \alpha ́ v \eta$. Soczewica podawana $w$ takiej formie, jako dodatek a nie podstawowy składnik, była chętniej polecana przez tego medyka niż zupy przygotowane wyłącznie z roślin strączkowych. Te ostatnie bowiem uznawano za mniej pożywne i bardziej wiatropędne od zup powstałych ze zbóż, a zatem gorsze dla osób w gorączce ${ }^{261}$.

Aecjusz z Amidy nie zamieścił w swoim dorobku interesujących danych, które $\mathrm{w}$ istotny sposób pogłębiłyby naszą wiedzę na temat przyrządzania soczewicy. W Iatricorum libri znajdujemy jednak ciekawy, ponieważ dość szczegółowy przepis na leczniczą $\tau \varepsilon v \tau \lambda$ $\propto \alpha \kappa \hat{\eta}$. Stanowi on uzupełnienie wiadomości, jakie uzyskaliśmy do tej pory. Owa zupa oparta była na mące z soczewicy ${ }^{262}$, gotowanej z octem oraz burakami ${ }^{263}$, z dodatkiem sumaka garbarskiego lub maku' ${ }^{264}$.

Antimus ${ }^{265}$, żyjący w tym samym wieku co Aecjusz z Amidy, pisał, że soczewica będzie dobrze przyrządzona, gdy się ją najpierw starannie wypłucze,

${ }^{255}$ To one zwykle używane były w gastronomii i medycynie greckiej. Korzenie, gdy ich zastosowanie wchodziło w grę $\mathrm{w}$ danej recepturze, były zawsze osobno wyspecyfikowane $\mathrm{w}$ przepisie.

${ }^{256}$ Por. Oribasius, Collectiones medicae IV 7, 23, 2 - 24, 1.

${ }^{257}$ Por. tamże IV 7, 23, 1 - 24, 1.

${ }^{258}$ Por. tamże IV 7, 24, 1-3.

${ }^{259}$ Por. tamże IV 8, 1, 1 - 18, 3.

${ }^{260}$ Por. tamże IV 8, 5, 1-3.

${ }^{261}$ Por. tamże IV 8, 5, 1 - 7, 3.

${ }^{262}$ Por. Aetius Amidinus, Iatricorum libri III 119, 5-6.

${ }^{263}$ Por. tamże III 119, 6.

${ }^{264}$ Por. tamże III 119, 5-7.

${ }^{265}$ Antimus był bizantyńskim lekarzem żyjącym na przełomie V i VI w. po Chr. Cytowane poniżej dzieło jego autorstwa zostało napisane po łacinie. Jest ono poświęcone różnym rodzajom pożywienia i wpływowi, jaki wywiera ono na zdrowie człowieka. Praca ta zawiera nie tylko zbiór wartościowych rad, ale i szereg ówczesnych przepisów kulinarnych. Stanowi ona źródło do poznania zarówno kuchni bizantyńskiej, jak i diety galijskiej, autor przebywał bowiem przez pewien czas na dworze Teuderyka, króla Franków; por. G.M. Messing, Remarks on Anthimus De observatione ciborum, CPh 37 (1942) fasc. 2, 150-158; M. Grant, Introduction, w: Anthimus, On the Observance 
a następnie ugotuje $\mathrm{w}$ świeżej wodzie. Pierwsza woda $\mathrm{z}$ gotowania musi być odlana, a po pozbyciu się jej wlewa się do ziaren kolejną porcję płynu, by po-

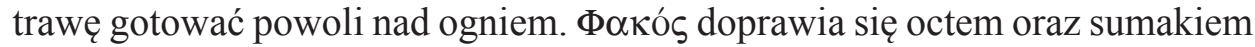
syryjskim. Tego ostatniego należy wziąć łyżeczkę i dosypać do dania, gdy jest ono nadal na ogniu, następnie dokładnie je zamieszać, zdjąć z paleniska i podać do zjedzenia. Do drugiej wody, w której gotuje się soczewicę, można dolać oliwy typu ỏ $\mu \varphi \alpha ́$ kıvov. Dobrze jest też dołożyć jedną lub dwie rośliny kolendry (całej, z korzeniami), a nadto nieco soli ${ }^{266}$.

Działalność pisarska Pawła z Eginy również nie wnosi wiele nowego do naszej wiedzy na temat miejsca, jakie soczewica zajmowała w kuchni. Potwierdza natomiast znakomicie stałość zasad i metod wykorzystania pokós jako pokarmu. $Z$ tekstu wnosić wypada, że soczewica była nadal spożywana powszechnie, gdyż w ogólnej charakterystyce roślin strączkowych pojawia się jako pierwsza ${ }^{267}$. Musiała być zresztą w rzeczywistości istotnym środkiem, który Paweł miał do swojej dyspozycji jako lekarz, ponieważ wymienia ją w swoich tekstach stosunkowo często. Z generalnego opisu ő $\sigma \pi \rho ı \alpha$ wynika również, że roślina ta $\mathrm{w}$ dalszym ciągu stanowiła podstawę do przygotowywania dań gotowanych, a zatem zupy typu $\varphi \propto \kappa \hat{\eta}$ we wszystkich jej odmianach $^{268}$. Tradycyjnie przekazywaną w literaturze dietetycznej informacją jest wzmianka o metodzie redukcji wiatropędności potraw z soczewicy. Sposobem na to było dodanie do pożywienia takich ziół jak cząber i mięta polejé ${ }^{269}$. Wnioski dotyczące metod przyrządzania interesującego nas pożywienia potwierdza

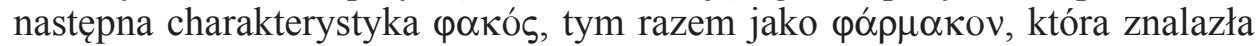
się w siódmej księdze dzieła medyka z Eginy ${ }^{270}$. Jest tam bowiem mowa między innymi od dwukrotnym gotowaniu soczewicy jako o właściwej metodzie ograniczania czy nawet eliminowania jej zdolności do pobudzania przewodu pokarmowego do wydalania.

W końcu, w następnym chronologicznie dziełku De cibis, znajdujemy podobne wskazówki co do metody gotowania soczewicy. Mianowicie dwa fragmenty tego traktatu podają, iż zwykle poddawano ją procesowi obróbki ciepl-

of Foods. De observatione ciborum, ed., transl. M. Grant, Totnes - Blackawton 2007, 1-6; J. Scarborough, Anthimus (of Constantinople?), EANS 91-92.

${ }^{266}$ Por. Anthimus, De observatione ciborum 67 (w niniejszym opracowaniu posłużono się wydaniem: Anthimi De observatione ciborum ad Theodoricum regem Francorum epistula, ed. E. Liechtenhan, Berolini 1963).

${ }^{267}$ Por. Paulus Aegineta, Epitomae medicae I 79, 1, 1-19.

268 To ostatnie stwierdzenie jest jedynie supozycją, gdyż Paweł nie wymienił terminów

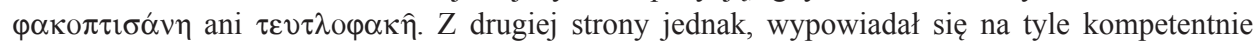
o przygotowywaniu $\pi \tau \iota \sigma \alpha ́ v \eta$ (np. tenże, Epitomae medicae I 78, 1, 21-25) i miał wystarczająco wiele do powiedzenia o burakach i ich właściwościach (np. tamże I 74, 1, 6-8), byśmy mogli uznać, że poruszał się w rzeczywistości kulinarno-medycznej, która była identyczna z tą, jaką opisywali jego poprzednicy piszący wiele zarówno o

${ }^{269}$ Por. Paulus Aegineta, Epitomae medicae I 79, 1, 1-4.

${ }^{270}$ Por. tamże VII 3, 21, 2-5. 
nej w wodzie aż dwukrotnie ${ }^{271}$, a czyniono to po to, by uzyskać odpowiednie wartości tego pokarmu.

Ponadto, wypada wspomnieć, że dokładne receptury na przygotowanie soczewicy znalazły się w jedynej zachowanej do naszych czasów w całości książce kucharskiej starożytności, a mianowicie w dziełku $O$ sztuce kulinar$n e^{272}$. Fakt ten jest kolejnym argumentem przemawiającym za jej stałym $\mathrm{i}$ istotnym znaczeniem w kuchni, a zatem także w diecie ludzi zamieszkujących basen Morza Śródziemnego.

Dokonana przez nas analiza treści Historia religiosa Teodoreta z Cyru, w której skupiliśmy się na poznaniu szczegółów dotyczących diety syryjskich mnichów, dowodzi przydatności tego źródła w badaniach poświęconych życiu codziennemu ludzi epoki IV i V w. Biskup stosunkowo chętnie dzieli się ze swoimi czytelnikami informacjami na temat produktów spożywczych, jakimi posilali się asceci. Wśród nich kilkakrotnie wymienia soczewicę, pozwalając nam tym samym uznać, że musiała ona stanowić istotny element jadłospisu świętych mężów.

Co zadecydowało o popularności tego właśnie pokarmu w środowisku, o którym mowa? Zasady religijne, jakimi w swoim życiu kierowali się mnisi, zakładały jak najskromniejszą egzystencję, bowiem tylko ta - ich zdaniem - prowadziła do Boga. Takie podejście wykluczało między innymi wszelkie luksusy kulinarne. Soczewica była w regionie śródziemnomorskim rośliną od dawna znaną i uprawianą. Jej powszechność sprawiła, że można ją było łatwo nabyć za niezbyt wygórowaną cenę. Współcześni badacze uznają ją za pożywienie właściwe członkom mniej zamożnych warstw społeczeństwa. $\mathrm{Ci}$ ostatni jednak, w przeciwieństwie do bohaterów dzieła Teodoreta, sięgali po

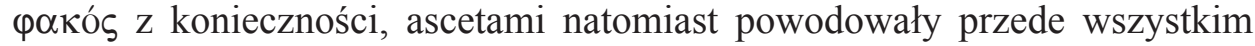
wymienione wyżej względy religijne.

W swoim studium pokusiliśmy się o zestawienie ze sobą bardzo odmiennych tematycznie i gatunkowo źródeł, jakimi są dzieło reprezentujące historiografię patrystyczną oraz traktaty medyczne pochodzące z okresu między II a VII w. Nasze badania dowodzą celowości tego typu konfrontacji. Pisma późnoantycznych i wczesnobizantyńskich lekarzy dają możliwość rekonstrukcji ówczesnej diety i technologii obróbki żywności. Ich autorzy poświęcili sporo uwagi omówieniu dietetycznego, medycznego i kulinarnego wykorzystania

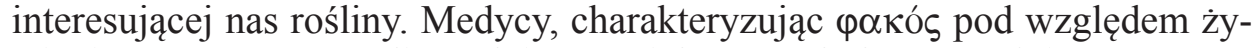
wieniowym, pozostawali zgodni w swoich ocenach, które ogólnie uznać możemy za negatywne. Owo warzywo strączkowe, ich zdaniem, jest pokarmem wiatropędnym, przyczynia się do osłabienia wzroku i zachwiania równowagi humoralnej, wysusza ciało. Ponadto, z jednej strony, sama soczewica powoduje spowolnienie pracy przewodu pokarmowego, z drugiej zaś, jej sok, przechodząc do wywaru powstałego w wyniku jej odgotowania, doprowadza do

\footnotetext{
${ }^{271}$ Por. De cibis XII 2-3; XIII 11-13.

272 Por. Apicius, De re coquinaria V 2, 1-3.
} 
przeczyszczenia. Wydaje się, że mnisi, wybierając soczewicę na swoje pożywienie, mogli kierować się nie tylko jej przystępną ceną i faktem, że w suchej postaci była ona łatwa do przechowywania. Za ich decyzją stała być może także fachowa wiedza medyczna - tą, jak pokazaliśmy wyżej, dysponował sam Teodoret, który miewał okazje, by podzielić się nią z syryjskimi pustelnikami.

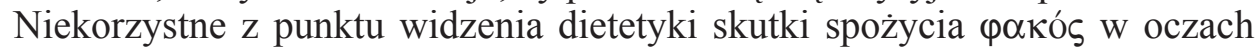
mnichów mogły uchodzić za zalety, gdyż sprawiały, że wysiłkom ascetycznym, jakie przed sobą stawiali, tym trudniej było sprostać. Mimo tego złego wpływu na organizm, soczewica została przez lekarzy uznana za pokarm pożywny. Uchodziła również za cenną substancję leczniczą i wykorzystywana była $\mathrm{w}$ wielu procedurach medycznych. Na marginesie rozważań dietetycznych i medycznych, będących głównym tematem traktatów, do których sięgnęliśmy, znajdujemy informacje mówiące o kulinarnym jej wykorzystywaniu. Pojawiające się tam przepisy, zarówno na dania proste, jak i te bardziej wykwintne, zakładają gotowanie jej ziarna. Tymczasem, w Historia religiosa mowa jest jedynie o zmiękczaniu go poprzez namaczanie. Przy takim postępo-

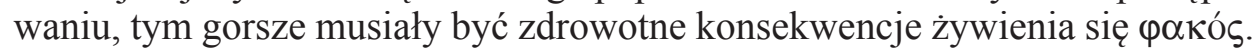
Za rezygnacją z poddawania nasion obróbce termicznej mogła kryć się między innymi chęć zaoszczędzenia czasu, tak by tym więcej przeznaczyć go modlitwę. Prawdopodobne wydaje się jednak, że podobnie jak Teodoret, także inni asceci znali krytyczne opinie medyków odnoszące się do energetycznej i dietetycznej wartości surowego pożywienia i celowo łamali zalecenia dotyczące właściwego przyrządzania tego pokarmu, gdyż dzięki temu mogli jeszcze bardziej poświęcać się w imię wyznawanej wiary.

\section{THE MONASTIC DIET IN THE LIGHT OF MEDICAL SCIENCE. THEODORET OF CYRUS AND PHYSICIANS ON LENTILS}

\section{(Summary)}

The present article discusses one of the most important ingredients of the Syrian ascetic diet (from the beginning of the $\mathrm{IV}^{\text {th }}$ to the mid $\mathrm{V}^{\text {th }}$ century) as described by Theodoret of Cyrus in his Historia religiosa, namely lentils ( $\varphi \alpha \kappa o ́ s)$. The basis of the research is constituted by ancient and byzantine medical treatises composed between the Ist and the VII ${ }^{\text {th }}$ centuries by Dioscurides, Galen, Oribasiusa, Aetius of Amida and Paul of Aegina. The aim of the article is to describe the role of the legume and thereby opine on compatibility or incompatibility of the monastic dietetic pattern with the one described by the medical doctors.

First, the authors of the study try to show the importance of lentils as food across the area of the Mediterranean. Subsequently, they proceed to sketch its dietetic characteristics developed by ancient and Byzantine medical doctors and conclude that the evaluation was not fully appreciative of the foodstuff. Thirdly, the authors come to show applications of lentils in medical procedures, since both 
in Antiquity as well as in Byzantium the plant was considered to be a medicine. The discussion on lentils is concluded by introducing culinary uses of lentils, which abound in medical writings. The authors also note that all the preserved recipes envisage the cooking of the food, i.e. a procedure which was usually avoided by the Syrian ascetics.

Key words: legumes as food in Antiquity and Byzantium, lentils, ancient and Byzantine gastronomy, ancient and Byzantine medicine, Syrian monks, Theodoretus of Cyrus.

Słowa kluczowe: konsumpcja roślin strączkowych w starożytności i Bizancjum, soczewica, antyczna i bizantyńska gastronomia, antyczna i bizantyńska medycyna, mnisi syryjscy, Teodoret z Cyru. 
